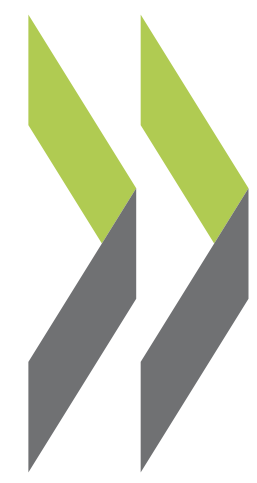

OECD Economics Department Working Papers No. 1117

\title{
Policies for Making \\ the Chilean Labour Market \\ More Inclusive
}

Aida Caldera Sánchez 
Organisation de Coopération et de Développement Économiques

Organisation for Economic Co-operation and Development

02-Jun-2014

ECONOMICS DEPARTMENT

English - Or. English

POLICIES FOR MAKING THE CHILEAN LABOUR MARKET MORE INCLUSIVE

ECONOMICS DEPARTMENT WORKING PAPERS No. 1117

By Aida Caldera Sanchez

OECD Working Papers should not be reported as representing the official views of the OECD or of its member countries. The opinions expressed and arguments employed are those of the author(s).

Authorised for publication by Robert Ford, Deputy Director, Country Studies Branch, Economics Department.

All Economics Department Working Papers are available through OECD's Internet website at www.oecd.org/eco/workingpapers

JT03358454

Complete document available on OLIS in its original format

This document and any map included herein are without prejudice to the status of or sovereignty over any territory, to the delimitation of international frontiers and boundaries and to the name of any territory, city or area. 
OECD Working Papers should not be reported as representing the official views of the OECD or of its member countries. The opinions expressed and arguments employed are those of the author(s).

Working Papers describe preliminary results or research in progress by the author(s) and are published to stimulate discussion on a broad range of issues on which the OECD works.

Comments on Working Papers are welcomed, and may be sent to the Economics Department, OECD, 2 rue André-Pascal, 75775 Paris Cedex 16, France, or by e-mail to eco.contact@oecd.org.

This document and any map included herein are without prejudice to the status of or sovereignty over any territory, to the delimitation of international frontiers and boundaries and to the name of any territory, city or area.

The statistical data for Israel are supplied by and under the responsibility of the relevant Israeli authorities. The use of such data by the OECD is without prejudice to the status of the Golan Heights, East Jerusalem and Israeli settlements in the West Bank under the terms of international law.

\section{(C) OECD (2014)}

You can copy, download or print OECD content for your own use, and you can include excerpts from OECD publications, databases and multimedia products in your own documents, presentations, blogs, websites and teaching materials, provided that suitable acknowledgment of OECD as source and copyright owner is given. All requests for commercial use and translation rights should be submitted to rights@oecd.org 


\section{ABSTRACT/RESUMÉ POLICIES FOR MAKING THE CHILEAN LABOUR MARKET MORE INCLUSIVE}

Economic growth and recent policy reforms have increased employment and reduced overall poverty in Chile. Yet there are some groups that remain at the margins of the labour market and could benefit from and contribute more to growth. Women and young people have entered the labour force in greater numbers, but their participation rates remain low compared to most OECD and Latin American countries. The participation of women in the labour market is held down by economic, cultural and regulatory barriers. For youth, poor basic skills acquired through compulsory education and the weak linkages between secondary education and job related skills often limit their employment prospects. Among lowskilled workers, a high minimum wage and strict employment protection pose a barrier to employment. At the same time, education and training policies do not sufficiently reach those with poor skills and the public employment services lack the capacity to deliver high quality job-search services. The paper discusses a number of policies that could help to make the Chilean labour market more inclusive and broaden the benefits of growth. These include expanding childcare, promoting a more flexible labour market and strengthening education and skills policies, among others.

This Working Paper relates to the 2013 OECD Economic Survey of Chile (www.oecd.org/eco/surveys/economic-survey-chile.htm).

JEL Codes: J1, J16, J21, J24, J3, J7

Key words: Chile, female employment, labour market policies, low-skilled workers, youth employment $* * * * * * * * * * * * * * * * * * * * * * * * * * * * * * * * * * * * * * * * * * * * * * * * *$

\section{DES POLITIQUES POUR RENDRE LE MARCHÉ DU TRAVAIL CHILIEN PLUS INCLUSIF}

La croissance économique et les réformes récentes ont accru le niveau d'emploi et réduit la pauvreté globale au Chili. Pourtant, il y a certains groupes qui restent en marge du marché du travail. Les femmes et les jeunes sont de plus en plus nombreux à investir le marché du travail, mais leur taux d'activité reste faible par rapport à ceux de la plupart des pays de l'OCDE et d'Amérique latine. La participation des femmes sur le marché du travail est tenu par des obstacles économiques, culturels et réglementaires. Pour les jeunes, les faibles compétences de base acquises par l'éducation obligatoire et la faiblesse des liens entre l'enseignement secondaire ainsi que les compétences professionnelles limitent souvent leurs perspectives d'emploi. S'agissant des travailleurs peu qualifiés, l'existence d'un salaire minimum élevé et d'une protection de l'emploi rigide freinent l'accès à l'emploi. Dans le même temps, les politiques d'éducation et de formation ne parviennent pas suffisamment à ceux ayant de faibles capacités et les services publics de l'emploi n'ont pas la capacité de fournir des services de recherche d'emploi de haute qualité. Cette étude examine un certain nombre de politiques qui pourraient contribuer à rendre le marché du travail chilien plus inclusif et à élargir les bénéfices de la croissance. Il s'agit notamment de l'extension des services d'accueil des enfants, l'assouplissement du marché du travail et le renforcement des politiques éducatives et de développement des compétences, parmi d'autres mesures.

Ce Document de travail se rapporte à l'Étude économique de l'OCDE de Chili 2013 (www.oecd.org/fr/eco/etudes/chili-2013.htm).

Codes JEL: J1, J16, J21, J24, J3, J7

Mots-clés: Chili, emploi des femmes, politiques du marché du travail, travailleurs peu qualifiés, emploi des jeunes 


\title{
TABLE OF CONTENTS
}

\author{
POLICIES FOR MAKING THE CHILEAN LABOUR MARKET MORE INCLUSIVE …......................5 \\ Overview of recent labour market developments and challenges ............................................................ 5 \\ Recent labour market performance has been strong overall .................................................... 5

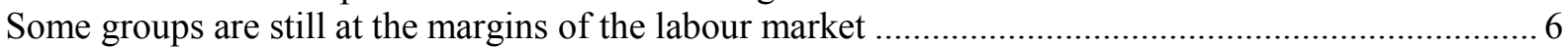

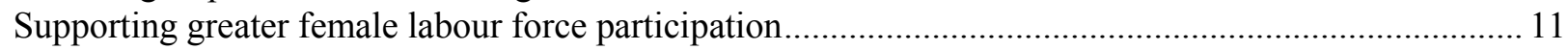

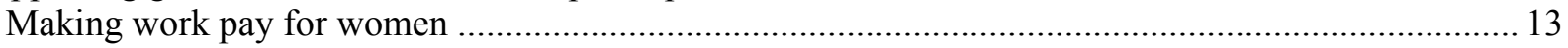

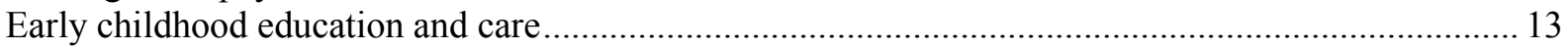

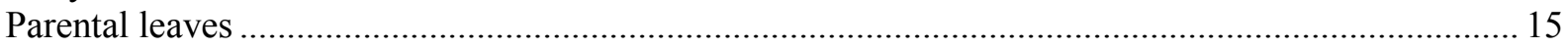

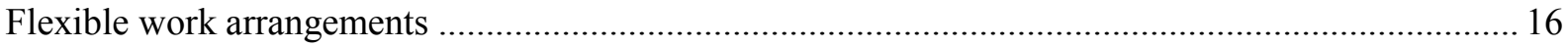

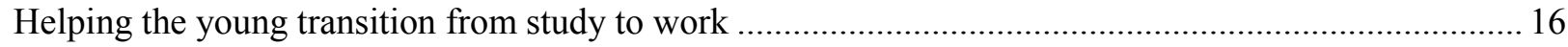

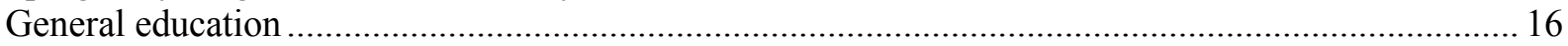

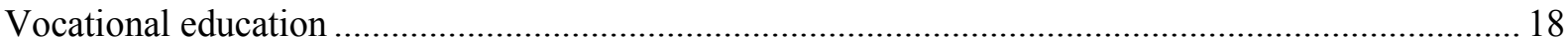

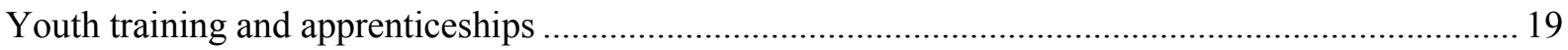

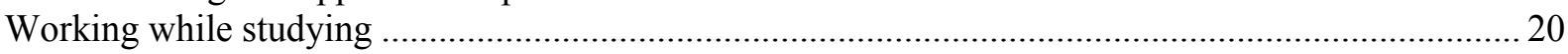

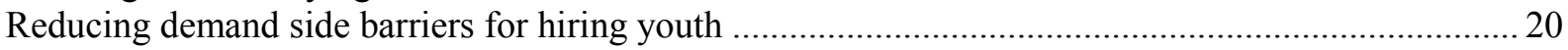 \\ The low skilled need help to improve their skills and find better jobs................................................ 21

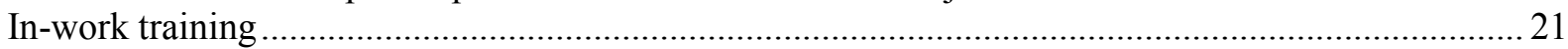

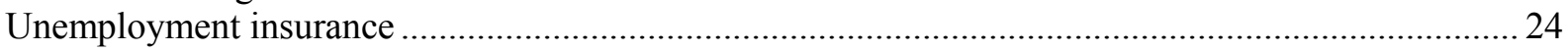

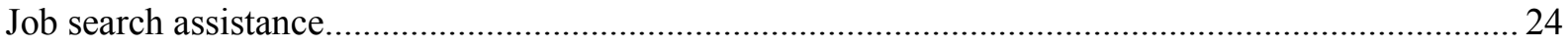

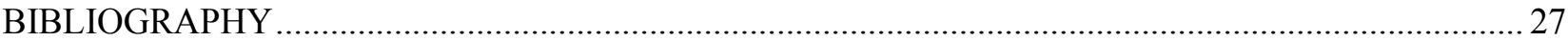

\section{Tables}

1. Summary of labour market and training programmes and recommendations..................................... 12

\section{Figures}

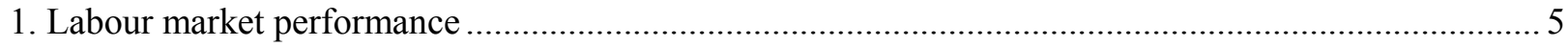

2. Bringing more women into the labour force could help to sustain labour supply in Chile .................... 7

3. Disposable income inequality has fallen but is still very high ........................................................... 8

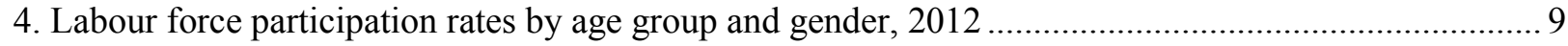

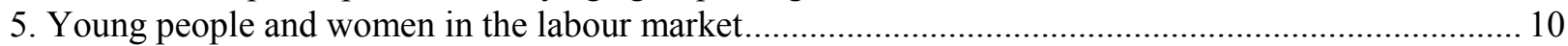

6. Coverage of early childhood education and care ............................................................................ 14

8. Percentage of 25-64 year-olds in employment, by educational attainment level (2011) .................... 17

9. Combining study and work can be an effective pathway to enter the labour market........................... 20

10. The effect of the proposed unemployment benefit reform on replacement rates (net of taxes), 201124

\section{Boxes}

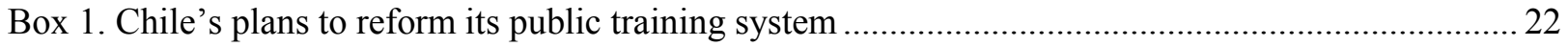

Box 2. Recommendations to improve labour market inclusiveness........................................................ 26 
ECO/WKP(2014)13

\title{
POLICIES FOR MAKING THE CHILEAN LABOUR MARKET MORE INCLUSIVE
}

\author{
by Aida Caldera Sánchez ${ }^{1}$
}

\section{Overview of recent labour market developments and challenges}

\section{Recent labour market performance has been strong overall}

1. Recent labour market performance has been very good. Chile is one of the few OECD countries where unemployment rates are now lower than at the start of the crisis (Figure 1). Moreover, unemployment rates have reached record low levels. Since late 2011, the unemployment rate has fluctuated around $6 \frac{1}{2}$ per cent, the lowest in the past 15 years. Accordingly, real wages have been rising, though their growth has recently been volatile (Figure 1).

Figure 1. Labour market performance

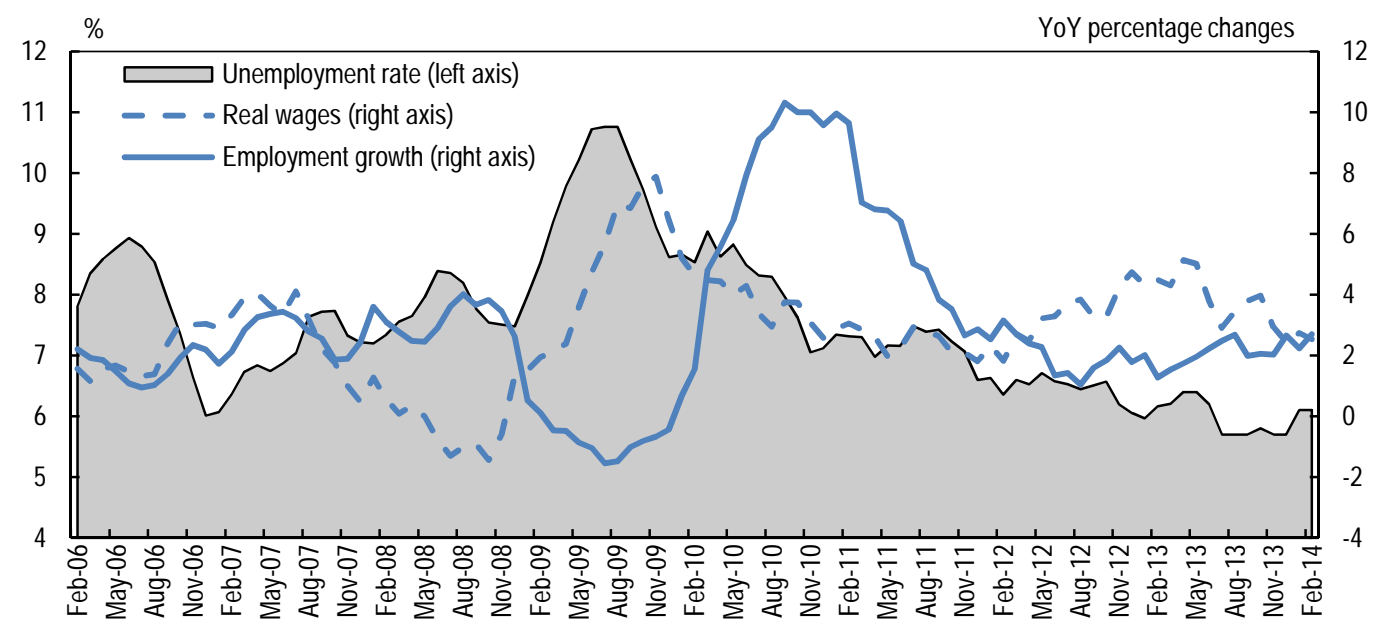

Note: The methodology was changed in January 2010 for the real wages and in April 2010 for the unemployment and employment rate. The change in the methodology for the employment and unemployment rate results in a break in the series which leads to the old and new series not being comparable.

Source: Instituto Nacional de Estadísticas (INE), Encuesta Nacional de Empleo (ENE), Nueva Encuesta Nacional de Empleo (NENE).

2. Job creation has also been strong. More than two million new jobs, accounting for $13 \%$ of total employment, have been created since 2000, half of which have been created since 2010. Most of these are full-time $(82 \%)$ and are in the formal sector, with a written contract and with employers making the contributions towards pensions, health care and unemployment insurance (Parro and Reyes, 2013).

\footnotetext{
${ }^{1}$ This paper was originally prepared for the OECD Economic Survey of Chile published in October 2013 under the authority of the Economic and Development Review Committee. The author is a member of the Economics Department of the OECD. The author is grateful to Willem Adema, Stjin Broecke, Alejandra Candia, Andrew Dean, Sean Dougherty, Robert Ford, Sean Gibson, Paulina Granados, David Grubb, Mario Marcel, Guillermo Montt, Francisca Müller, Patrick Lenain, Francisco Parro, Andrea Repetto, Paulo Santiago and several Chilean government officials for valuable discussions, comments and suggestions on earlier drafts. Special thanks go to Valery Dugain and Roselyne Jamin for statistical assistance, William Lobo for research assistance and Heloise Wickramanaye for assistance in preparing the document.
} 
3. A solid economic growth has boosted labour demand. But, there are other factors that could explain the employment recovery after financial crisis as well. Fiscal policy provided some support, as part of the 2009 fiscal stimulus was channelled through employment subsidies. When the unemployment rate rose above $10 \%$ during the global economic crisis, the government financed temporary emergency programmes. Young workers were a particular target group, with a subsidy for employers hiring workers aged 18 to 24 years (Subsidio al Empleo Jóven). On top of that, the reconstruction temporarily boosted the demand for workers in labour-intensive industries, especially construction. The mining and agriculture sectors, though less intensive in jobs, have also taken advantage of high commodity prices to increase employment. At the same time, important policy reforms, such as extended early-childhood education and maternity leave and the new in-work benefit for low-income women (Bono al Trabajo de la Mujer), have aimed at fostering female labour participation.

4. Methodological changes to the Labour Force Survey are not the main explanation for the solid employment performance. In 2010, the National Institute of Statistics replaced the National Employment Survey (ENE) with the New National Employment Survey (NENE) to align Chile with OECD best practices in the measurement of employment, unemployment and inactivity. This change may have unintentionally upward biased employment figures. The old survey recorded as employed only those people who spent most of the week working, whereas the new survey does it for everybody earning a salary for at least one hour per week. The impact is hard to assess because the old and the new surveys did not overlap. Nonetheless, an employment and unemployment survey conducted by the University of Chile, which covers only Santiago and has not undergone any methodological changes, shows broadly similar positive developments to those shown by the NENE (Parro and Reyes, 2013).

\section{Some groups are still at the margins of the labour market}

5. Women often do not participate in the labour market. They are less likely to have paid work than men, are more frequently unemployed and, when employed, they work more often in the informal sector or in low-paid jobs. As well, access to jobs is difficult for young people. And weak public employment and training systems compound the difficulties for the low skilled to access better jobs and to improve their earnings. Thus supporting policies are needed to ensure that women, youth and low-skilled individuals, can develop their full potential in the labour market. Although including these groups in the labour market is a high priority, there may be other groups that deserve attention, such as older workers and immigrants.

6. By fostering labour-force participation among these groups, in particular women, policies can contribute to economic growth and higher welfare, in part by increasing labour supply despite population ageing (Figure 2). Back in 1990, Chile's fertility rate was 2.6 children per woman. By 2011, that figure had dropped to 1.9, matching Brazil as the lowest fertility rate in South America. 
ECO/WKP(2014)13

Figure 2. Bringing more women into the labour force could help to sustain labour supply in Chile

Projected number of persons aged 15-64 in the labour force (thousands)

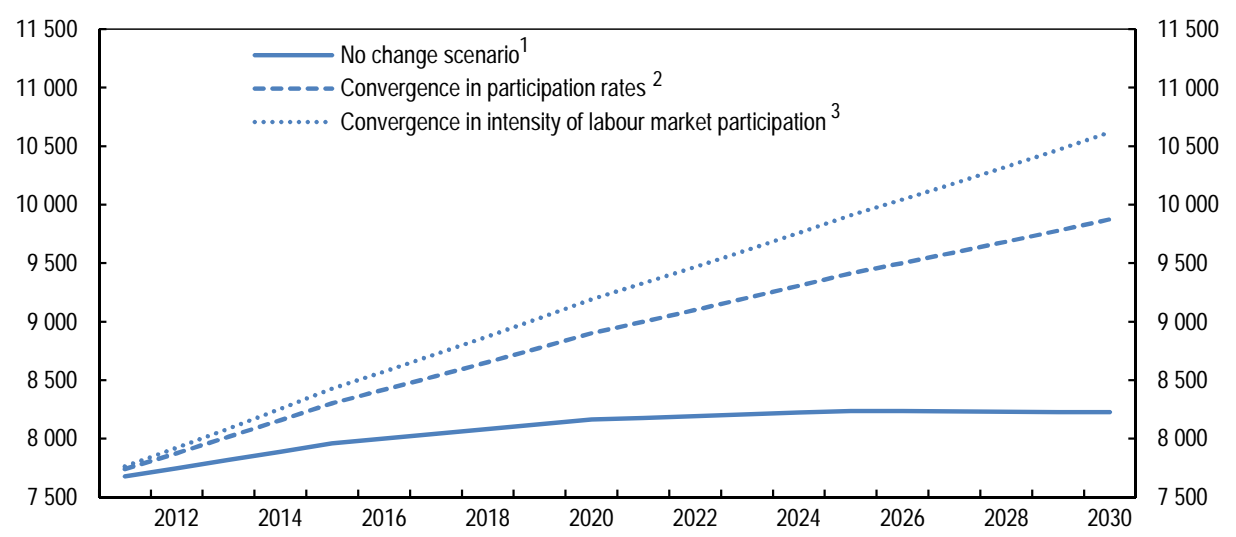

1. Projected size of the labour force, assuming that the participation rates for men and women remain constant at the 2010 rates.

2. Projected size of the labour force, assuming that the participation rate for men remains constant at the 2010 rates, and the rate for women shows a gradual increase reaching the 2010 rate for men by 2030.

3. Projected size of the labour force, assuming that the participation rate for men remains constant at the 2010 rate, and the full-time time equivalent rate for women shows a gradual increase reaching the 2010 full-time equivalent rate for men by 2030 .

Source: CELADE, Population division of ECLAC, 2012 Revision; OECD, Closing the Gender Gap: Act Now.

7. Greater labour-market inclusion of these marginal groups can also reduce poverty. Chile has made important progress in reducing poverty, as measured by anchored relative poverty (See OECD, 2013a), although it is still the most unequal country in the OECD (Figure 3). Policies that foster greater labour-market participation can help the most vulnerable to move up the wage ladder. These include labour-market policies, but most notably access to good quality education and skills policies, as discussed below. 
Figure 3. Disposable income inequality has fallen but is still very high ${ }^{1}$
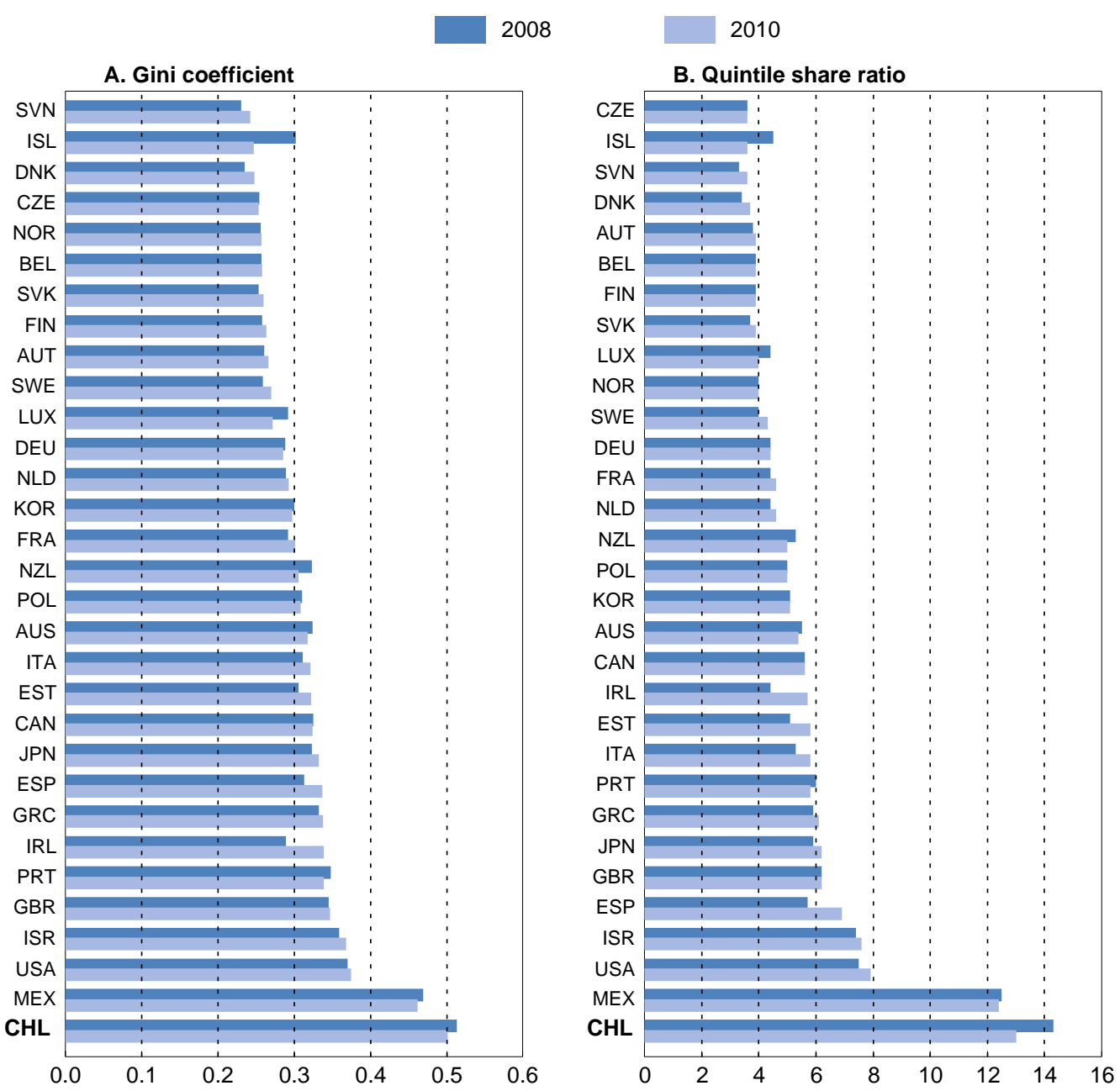

1. Population aged 18-64. 2009 and 2011 for Chile, 2006 and 2009 for Japan and 2008 and 2009 for Ireland and New Zealand.

Source: OECD Income Distribution Database.

How to read this figure: The Gini coefficient is a measure of income inequality that ranges from 0 (income is shared equally) to 1 (one person has all the income). The quintile share ratio is the ratio of total income received by the $20 \%$ of the population with the highest income (top quintile) to that received by the $20 \%$ of the population with the lowest income (lowest quintile).

\section{Women}

8. Female labour-force participation has increased significantly since the mid-1990s, and has been converging toward OECD levels at a faster pace than in other lagging OECD countries, though it remains very low. The situation is most acute for young women, whose employment rates remain remarkably low by international standards and also as compared to young men in Chile (Figure 4). One reason is that Chilean mothers tend to have their first child at a lower age than in other countries, with a significant incidence of teenage pregnancies among those with relatively low education and low household incomes (OECD, 2009). But there are also gender gaps in employment rates for older women. 
Figure 4. Labour force participation rates by age group and gender, 2012

In percentage
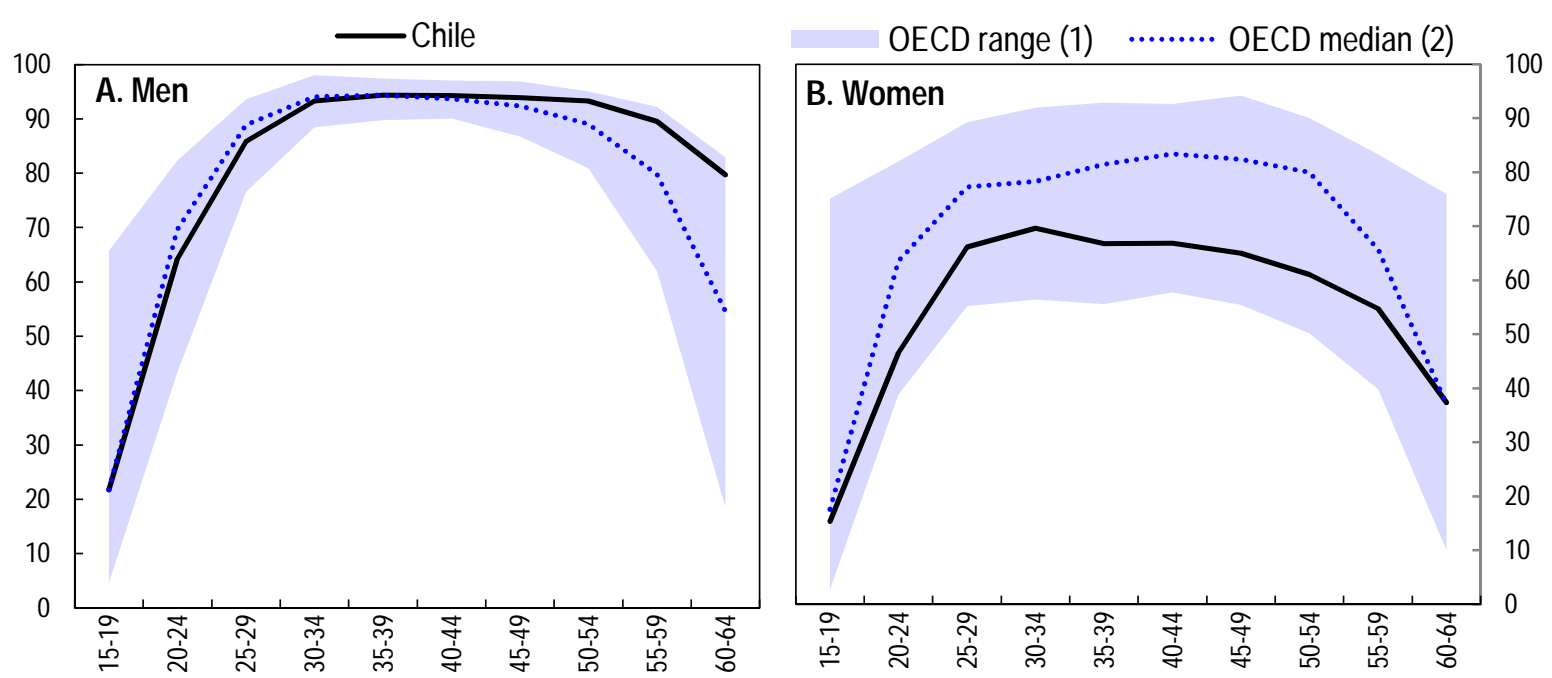

1. Range between the highest and lowest participation rate for each age group among OECD countries, excluding Israel and Turkey.

2. Excluding Israel (no data available) and Turkey (outlier for the participation rate of women).

Source: OECD (2012), Labour Force Statistics database.

9. Female salary workers working full-time earn on average $16 \%$ less than their male counterparts in Chile (OECD, 2013b). OECD estimates show that in Chile job characteristics is the main contributor to this gap, although as with all countries there is a large "unexplained" component that may be due to discrimination (OECD, 2012b). Women tend to work in sectors where salaries are lower, as for instance domestic work, or the public sector and are also more likely to work part-time than men (Medina and Paredes, 2013).

10. Women are also over-represented in informal jobs. About $40 \%$ of women in the lowest income quintile do not have a contract, compared to $22 \%$ of men, according to household surveys (CASEN 2011). Informality leads to lower salaries and a greater risk of poverty, but can also lead to weak labour market attachment.

11. Informal jobs imply lower retirement benefits for women, who have incomplete contributory periods and thus cannot claim a full pension. When men retire, they receive a pension equivalent to $70 \%$ of their average salary during the last 10 years, while for women it is on average $51 \%$, according to the Superintendencia de Pensiones. In addition, women's pensions are based on lower salaries than men's. Hence, women retire with lower pensions and, because they live several years longer than men, they are at a greater risk of poverty.

\section{Youth}

12. The fall in unemployment over the past three years has been broad based, benefiting men and women of all age groups. Youth unemployment was historically high in 2009, but has fallen since then thanks to the rapid economic recovery and fiscal measures targeted at the young. Youth unemployment now stands at its lowest level of the past 13 years, and male youth unemployment rates are below those in the average OECD country. But for young women there is still a significant gap compared to the average OECD country (Figure 5, Panel A). 
Figure 5. Young people and women in the labour market

\section{A. Labour market indicators, 2012}
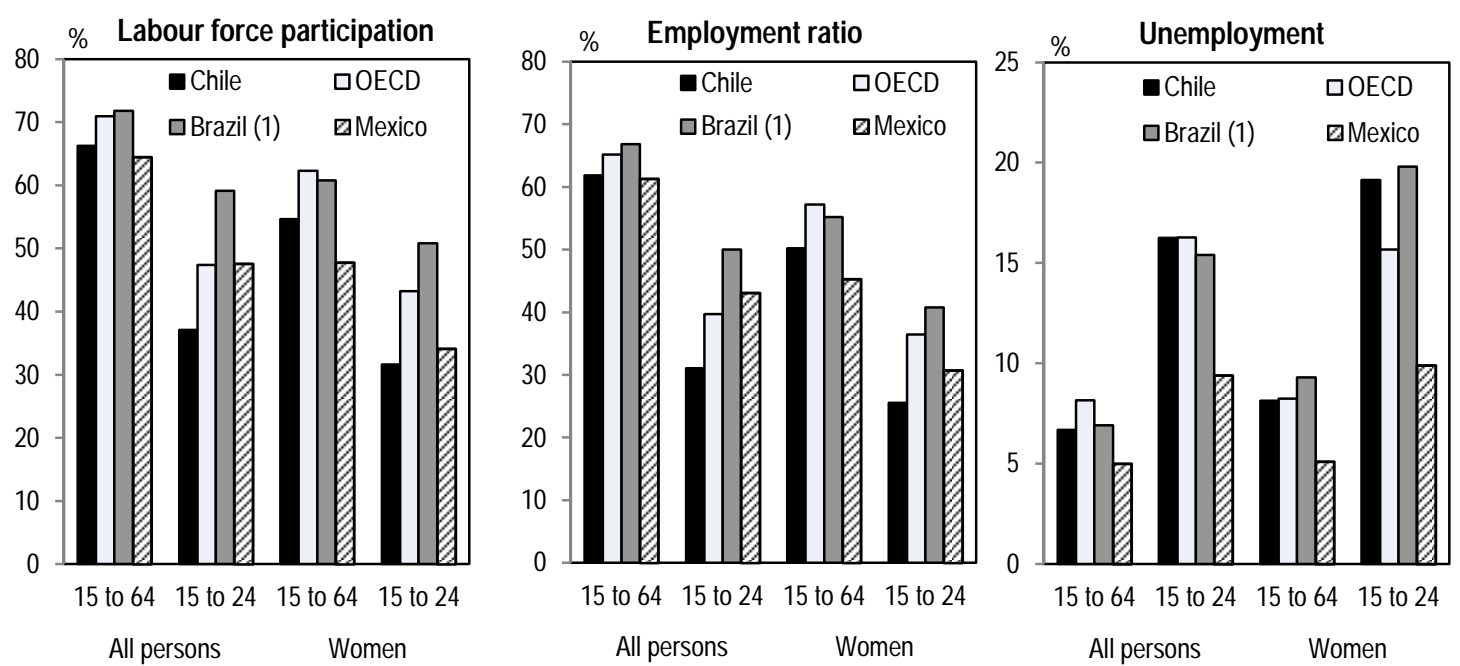

B. Percentage of 15-29 years-olds neither in employment nor in education (NEET) by gender, $2011^{2}$

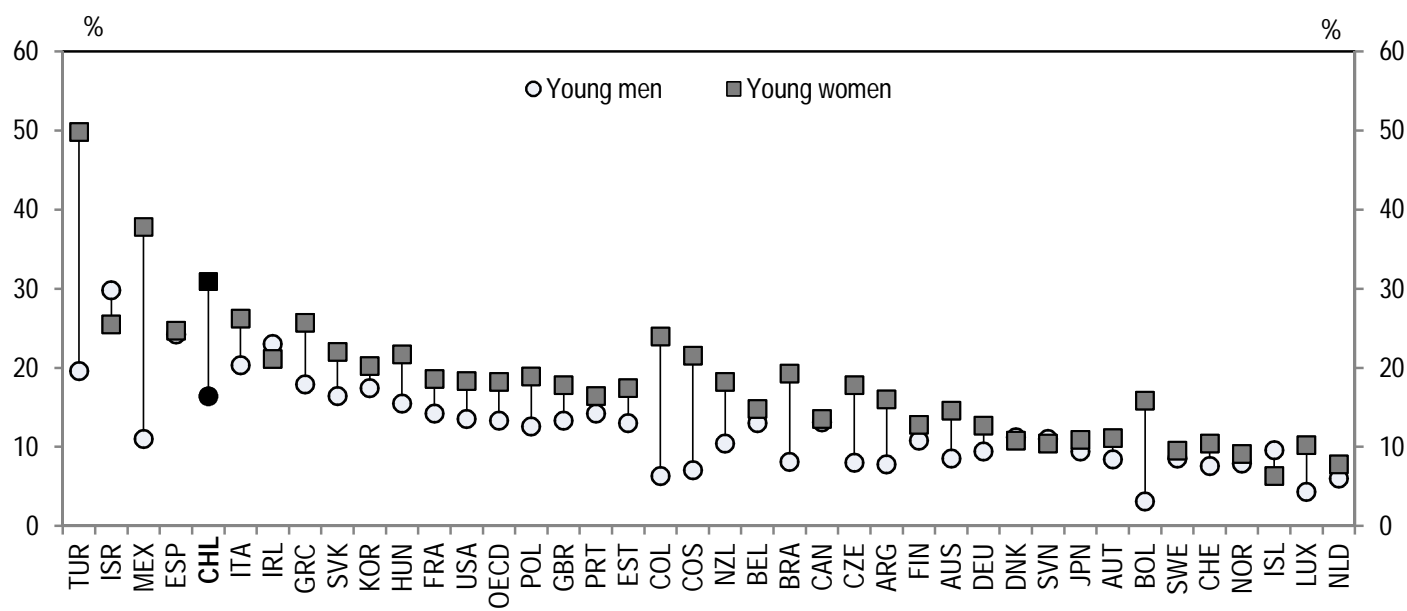

1. Data for Brazil refer to 2011.

2. Countries are ranked in descending order of the proportion of 15-29 year olds NEET in 2011. 2010 for Colombia and Costa Rica. Source: OECD, Labour Force Statistics database; Education at a Glance, 2013; SITEAL.

13. Another worrying feature is the high proportion of young Chileans aged 15-29 who are neither in education, employment or training $(24 \%)$ - the so-called NEETs. The proportion of NEETs stands above the OECD average (16\%) and above that of other countries in the region (Figure 5 Panel B). It has surprisingly remained stable over the past five years, despite the good economic environment, according to household surveys (CASEN, 2011).

14. Household data suggest that most of these young people come from the poorest households (CASEN, 2011). Many of them are women, who are almost three times more likely than young men to be NEETs, either because they do not have anyone to leave their children or elderly family with $(33 \%)$ or because of housework (36\%) (CASEN, 2011). This is a particularly important group to focus on as these individuals often face the greatest risk of economic and social exclusion. Available evidence from individual longitudinal data for the United States and Europe suggests that the NEET status can be very persistent, leading to a vicious circle whereby inactivity feeds into discouragement and that, in turn, to a further detachment from the labour market (Quintini and Manfredi, 2009). 


\section{The low skilled}

15. While rapid growth and good labour market performance has benefited many Chileans the lowskilled still have relatively unenviable labour market outcomes. For instance, low skilled workers are much more likely to oscillate between the formal and the informal sector and between inactivity and unemployment than workers with higher skills (OECD, 2012a). Low skilled workers benefit also from lower social protection (e.g. unemployment benefits, sickness coverage, severance pay) than high skilled workers, as they are more likely to work informally (OECD, 2009; Scarpetta and Sonnet, 2012). Informal employment, although has receded during the past three years, remains significant in Chile. About $20 \%$ of all Chilean employees did not have a formal contract or did not contribute to social security in 2011 (CASEN, 2011).

\section{Supporting greater female labour force participation}

16. The participation of women in the labour market is held down by economic barriers because work often does not pay enough to compensate the cost of childcare. The government has thus recently introduced reforms to extend early childhood education and childcare, extend maternity leave and make work pay more with an in-work benefit for low-income women (Bono al Trabajo de la Mujer). OECD experience suggests that these reforms bring more women into the labour force (OECD, 2012b; OECD, 2013c).

17. Cultural barriers also discourage many Chilean women from engaging in paid work. One such cultural barrier is the attitude towards the balance between work and family commitments. Most women who are not in the labour force are engaged in housework and childcare and, when Chilean parents are asked, many think that mothers should stay at home and take care of their children rather than work (Medina and Paredes, 2013). While house work has tangible economic value (Miranda, 2011) it does not contribute to female career opportunities and expected lifetime earnings. OECD experience suggests that a well-designed package of family-friendly policies, including affordable high-quality childcare, paternal leaves, opportunities to work part-time and flexible workplace arrangements, can reduce these cultural barriers and facilitate a more balanced sharing of responsibilities (OECD, 2012b). The potential for Chile to develop or expand these policies is discussed in what follows along with other recent government initiatives to support greater female labour force participation. Table 1. summarises the main recommendations on labour market and training programmes outlined in the chapter. 


\section{$\mathrm{ECO} / \mathrm{WKP}(2014) 13$}

\section{Table 1. Summary of labour market and training programmes and recommendations}

\begin{tabular}{|c|c|c|c|c|c|}
\hline Programme & $\begin{array}{c}\text { Nature of } \\
\text { programme }\end{array}$ & Description & Eligibility & Participation & Recommendation \\
\hline $\begin{array}{l}\text { Bono al Trabajo de la } \\
\text { Mujer }\end{array}$ & In-work benefit & $\begin{array}{l}\text { In place since } 2012 \text { as part of the new } \\
\text { cash transfer programme Ingreso Etico } \\
\text { Familiar. The benefit can go up to about } \\
34000 \text { pesos ( } 67 \text { USD) per month on } \\
\text { top of the Ingreso Etico Familiar } \\
\text { Transfer. It includes also a subsidy for } \\
\text { the employer to encourage labour } \\
\text { demand, which is half that given to the } \\
\text { employee. }\end{array}$ & $\begin{array}{l}\text { Women aged } 25-59 \text {, } \\
\text { belonging to the } 30 \% \\
\text { poorest households }\end{array}$ & $\begin{array}{l}\text { In } 2012,179719 \\
\text { women received the } \\
\text { benefit out of } 409531 \\
\text { applications. }\end{array}$ & $\begin{array}{l}\text { Evaluate its outcome and } \\
\text { expand according to the result } \\
\text { of the evaluation. Target the } \\
\text { benefit at women's wages only } \\
\text { without considering their } \\
\text { family income. Consider a } \\
\text { higher benefit for women with } \\
\text { young children. }\end{array}$ \\
\hline $\begin{array}{l}\text { Subsidio al Empleo } \\
\text { Jóven }\end{array}$ & In-work benefit & $\begin{array}{l}\text { In place since } 2009 \text {. The benefit } \\
\text { depends on monthly income and can } \\
\text { go up to a maximum of } 30 \% \text { of gross } \\
\text { monthly salary, two-thirds for the } \\
\text { worker and one-third for the employer }\end{array}$ & $\begin{array}{l}\text { Young workers } \\
\text { (dependent and } \\
\text { independent) aged 18- } \\
25 \text { belonging to the } \\
\text { poorest } 40 \% \text { of the } \\
\text { country's population } \\
\text { and with an annual } \\
\text { gross income below } \\
\$ 4,428,000 \\
\text { (9 } 129 \text { USD). }\end{array}$ & $\begin{array}{l}\text { In 2012, } 282377 \\
\text { subsidies awarded. }\end{array}$ & $\begin{array}{l}\text { Investigate the sources of low } \\
\text { employer participation and } \\
\text { improve the design to make it } \\
\text { more effective in encouraging } \\
\text { labour demand. }\end{array}$ \\
\hline $\begin{array}{l}\text { Formación en el } \\
\text { puesto de trabajo } \\
\text { (Aprendices) }\end{array}$ & Training & $\begin{array}{l}\text { Apprenticeship programme lasting } \\
\text { twelve months and combining on the } \\
\text { work-training with classroom-based } \\
\text { training, where the apprentice receives } \\
\text { half the minimum wage and the } \\
\text { company receives a training voucher as } \\
\text { to encourage additional training on the } \\
\text { side of the employer }\end{array}$ & $\begin{array}{l}\text { Young workers aged } \\
15-24\end{array}$ & $\begin{array}{l}\text { In } 2012,5623 \text { youth } \\
\text { benefited from the } \\
\text { programme. }\end{array}$ & $\begin{array}{l}\text { Evaluate its effectiveness and } \\
\text { consider expanding the } \\
\text { programme to cover more } \\
\text { youth according to the result } \\
\text { of the evaluation. }\end{array}$ \\
\hline $\begin{array}{l}\text { Formación para el } \\
\text { Trabajo (ex } \\
\text { Formación en } \\
\text { Oficios) }\end{array}$ & Training & $\begin{array}{l}\text { Training programmes to give } \\
\text { beneficiaries basic skills necessary for } \\
\text { job readiness (numeracy, basic } \\
\text { computer courses etc.). It may also } \\
\text { include internships. The Ministry of } \\
\text { Labour is running an impact evaluation } \\
\text { with a control and treatment group. }\end{array}$ & $\begin{array}{l}\text { Men and women aged } \\
18-65\end{array}$ & To date, 13593. & $\begin{array}{l}\text { Strengthen work-based } \\
\text { training components to } \\
\text { increase effectiveness }\end{array}$ \\
\hline $\begin{array}{l}\text { Formación para el } \\
\text { Trabajo Sectorial }\end{array}$ & Training & $\begin{array}{l}\text { In place since 2013, training } \\
\text { programmes based on industry needs. } \\
\text { The curricula have been designed by } \\
\text { SENCE in cooperation with the } \\
\text { industrial sectors. }\end{array}$ & $\begin{array}{l}\text { Men and women aged } \\
18-65 . \text { Some industries, } \\
\text { as mining, may have } \\
\text { different requirements } \\
\text { (health, age, technical } \\
\text { skills) }\end{array}$ & To date, 2,895 . & $\begin{array}{l}\text { Evaluate its effectiveness and } \\
\text { consider expanding the } \\
\text { programme to cover more } \\
\text { youth and/or more sectors } \\
\text { according to the result of the } \\
\text { evaluation. }\end{array}$ \\
\hline $\begin{array}{l}\text { Práctica profesional } \\
\text { en educación media } \\
\text { técnica profesional }\end{array}$ & $\begin{array}{l}\text { Vocational } \\
\text { education (post- } \\
\text { secondary) }\end{array}$ & $\begin{array}{l}\text { Mandatory traineeship to receive the } \\
\text { post-secondary VET degree }\end{array}$ & $\begin{array}{l}\text { Post-secondary VET } \\
\text { students }\end{array}$ & $\begin{array}{l}60 \% \text { of VET students } \\
\text { (MINEDUC, 2010) }\end{array}$ & $\begin{array}{l}\text { Integrate workplace training } \\
\text { into the body of upper } \\
\text { secondary vocational } \\
\text { programmes, rather than as a } \\
\text { separate part, as it is today. }\end{array}$ \\
\hline Student contract & Student contract & $\begin{array}{l}\text { The government has sent a draft bill to } \\
\text { congress that gives students aged } 18 \text { to } \\
25 \text { years old more flexible rules for } \\
\text { working by establishing a contract } \\
\text { through which the working day can be } \\
\text { interrupted several times every day. }\end{array}$ & $\begin{array}{l}\text { Students aged } 18 \text { to } \\
25 \text { years old }\end{array}$ & Not yet implemented & $\begin{array}{l}\text { Evaluate its effectiveness and } \\
\text { monitor that these jobs } \\
\text { become a stepping stone for } \\
\text { youth towards the labour } \\
\text { market rather than a dead end }\end{array}$ \\
\hline Franquicia Tributaria & Training & $\begin{array}{l}\text { Tax credit for firms sending their } \\
\text { workers to training }\end{array}$ & All workers & $\begin{array}{l}\text { In 2012, } 1660071 \\
\text { workers benefited from } \\
\text { the programme }\end{array}$ & $\begin{array}{l}\text { Improve training quality by } \\
\text { setting up standards, } \\
\text { establishing regular } \\
\text { performance assessments } \\
\text { and disseminating information } \\
\text { about providers. Improve } \\
\text { targeting by limiting training to } \\
\text { low skilled workers. Consider } \\
\text { second-chance education } \\
\text { options for low-skilled adults. }\end{array}$ \\
\hline $\begin{array}{l}\text { Other programmes } \\
\text { from the Fondo } \\
\text { Nacional de } \\
\text { Capacitación (e.g. } \\
\text { Mujeres Jefas del } \\
\text { Hogar, Bono al } \\
\text { Trabajador Activo) }\end{array}$ & Training & $\begin{array}{l}\text { Different training programmes for the } \\
\text { most vulnerable taught by training } \\
\text { institutions (OTEC) }\end{array}$ & $\begin{array}{l}\text { Most vulnerable } \\
\text { workers, including } \\
\text { women, youth and low } \\
\text { skilled workers }\end{array}$ & Not available & $\begin{array}{l}\text { Improve training quality by } \\
\text { setting up standards, } \\
\text { establishing regular } \\
\text { performance assessments } \\
\text { and disseminating information } \\
\text { about providers. }\end{array}$ \\
\hline
\end{tabular}


ECO/WKP(2014)13

\section{Making work pay for women}

18. A key reason why many low-income women do not work is because their salaries would be so low that it simply does not pay for them to work. To encourage more of these women to take up paid work, the government introduced an in-work benefit (Bono al Trabajo de la Mujer) in 2012, as part of the new cash transfer programme, Ingreso Etico Familiar. It builds on the successful experience of the in-work benefit for youth (Subsidio al Empleo Jóven) (Centro de Microdatos, 2012), and targets women among the $30 \%$ poorest households aged 25-59. The benefit can go up to about 34000 pesos (67 USD) per month on top of the Ingreso Etico Familiar transfer. It also includes a subsidy for the employer to encourage labour demand, which is half that given to the employee. In 2012, about 180000 women received the subsidy.

19. While the scheme has not been long enough in place to be thoroughly evaluated, OECD experience with in-work benefits and the Chilean experience with the youth subsidy (Centro de Microdatos, 2012) suggest that such benefits can encourage labour supply, though they usually have only a small effect on employment. As such, in-work benefits should not be seen as alternatives to deeper labour market reform, better education and effective training. In addition, work incentives of women and their family could be further enhanced if the in-work benefit was targeted at women's wages only, without considering family income. The benefit is now targeted on the Ficha de Protección Social score of the household (75\%), on the one hand, and on the annual household income $(25 \%)$, on the other. Such targeting makes sense when women are lone parents or the only breadwinner in the household. But OECD experience with these instruments suggests that targeting the subsidy on household earnings can have a negative effect on second earners incentives' to work (Immervol and Pearson, 2009).

20. There are other barriers that might limit the effectiveness of the in-work benefit for women with children, whose labour force participation is typically lower. The programme Chile Crece Contigo provides free access to childcare for kids belonging to the $60 \%$ poorest households, but sometimes high transport costs, opening hours not compatible with working hours, or simply a cultural preference for maternal care over formal care means that some mothers do not wish to make use of this service. One solution put forward by Huneeus and Repetto (2013) is that the subsidy could be higher for women with young children so as to recognise these additional costs, as is the case in the United States with the earned income tax credit.

\section{Early childhood education and care}

21. OECD evidence suggests that the availability of affordable, high-quality childcare is a key factor explaining cross-country differences in women's labour market participation (OECD, 2012b). In Sweden, for example, the expansion of child care services during the 1970s is thought to have helped increase women's employment rates from $60 \%$ to over $80 \%$ (OECD, 2012c). Facilitating access to good quality child care is important not only to encourage greater female labour supply, but also because international experience suggests that access to early childhood education can improve school outcomes later in life for disadvantaged children and mitigate social inequalities (e.g. Contreras et al., 2008; Ruhm and Waldfogel, 2011).

22. Besides, the availability of good and affordable childcare can increase the participation not only of mothers, but also of other household members who take care of children, like the elderly. For instance, earlier (Contreras et al. 2008) and recent analysis (OECD, 2013a; Lobo, 2014) finds that the presence of older household members increased the probability of the mother entering the labour market, as did the presence of a young woman in the household. This suggests that other household members contribute to childcare and caution should be taken so that childcare does not impede the employment and career opportunities of other household members, in particular young women. 
23. Since 1990 Chile has seen remarkable progress in increasing enrolments in early childhood education and care. Enrolment rates for children aged 4-5 (pre-kinder) have more than doubled, from 38\% to $83 \%$ (Figure 6, Panel A) and the government seeks to achieve universal coverage for children in the three lowest income deciles by 2014. There has been much progress also in enrolment for children aged 56 (kinder), with $90 \%$ enrolled. A bill is before Congress for a constitutional reform that will make their enrolment compulsory. Advancing towards the universal coverage of early childhood education for children aged 4-6 is an important goal that seems feasible and should be pursued. Investing in good quality education since the earliest years is the most effective way of reducing inequalities later in life because ability gaps open up in the first stages of life (Heckman, 2008).

Figure 6. Coverage of early childhood education and care
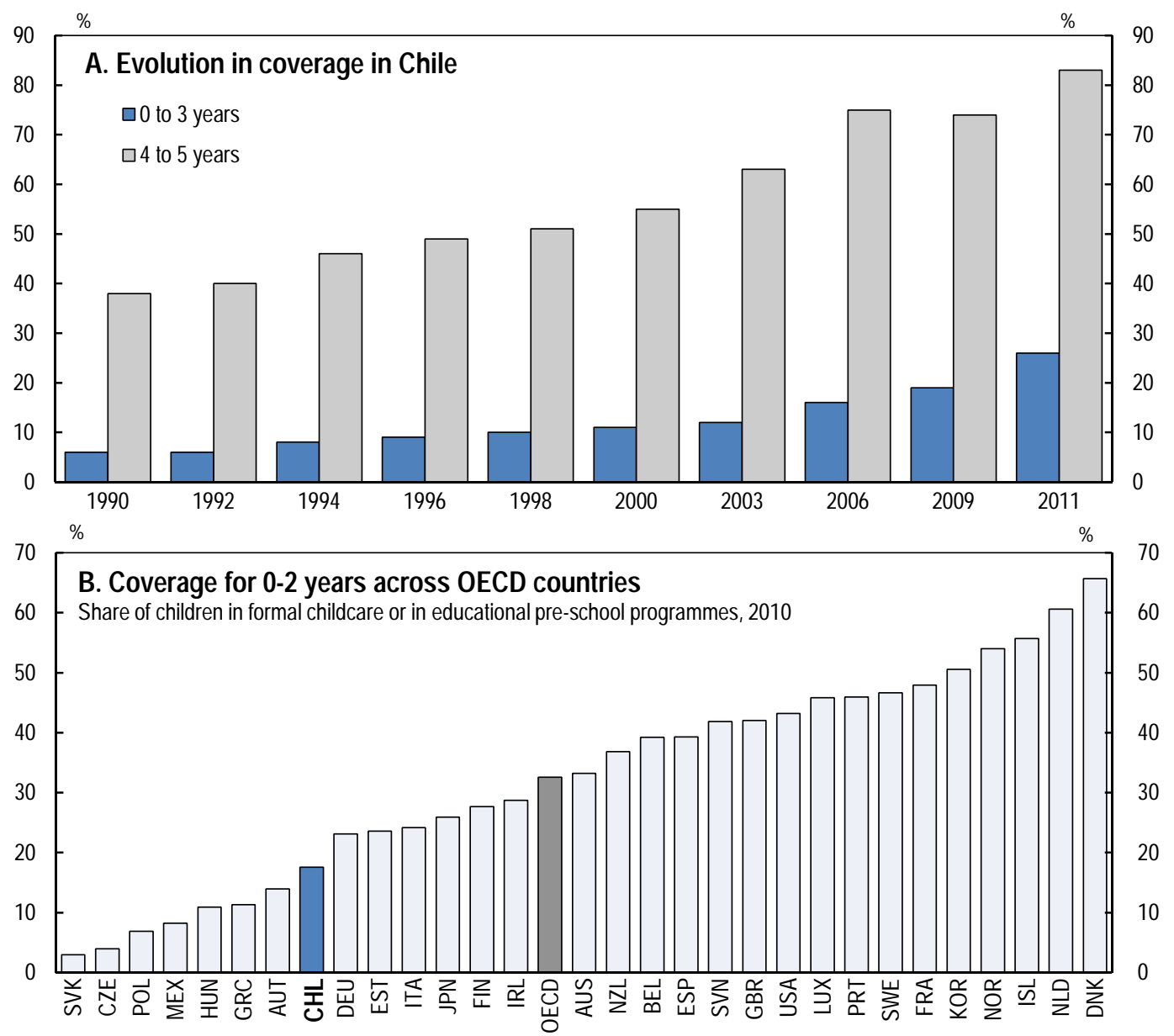

Source: CASEN (2011) and OECD Family Database.

24. Enrolment rates for children aged 3 years old or less, despite having quadrupled since 1990, are still low, with only $18 \%$ of children aged $0-2$ attending childcare, far below the OECD average of $33 \%$ (Figure 6, Panel B). A bill is before Congress to make universal and free access to education for children from 3 years old. OECD evidence suggests that the availability of affordable, high quality childcare is an important factor influencing female labour force participation, and it is during children's early years that it matters most, as the longer that mothers stay out of the labour force to take care of their children, the more difficult it is for them to get back to work (OECD, 2012b; Thévenon, 2013). International evidence suggests that access to childcare from a young age is also a good investment to improve cognitive outcomes of disadvantaged children, especially if education is sustained through mandatory schooling, and can mitigate social inequalities (e.g. Ruhm and Waldfogel, 2011). 
25. Companies employing 20 or more women have to cover childcare costs for employees' children during the child's first two years. This regulation can encourage greater female labour supply; but it also increases the cost of hiring women relative to men and represents a barrier to employment.

26. The government has sent a bill to amend this regulation, as recommended in the 2012 Survey (Brandt, 2012), which is welcome. The bill plans to give access to childcare to children up to 3 years old of all working mothers regardless of firm size. The new system will be financed with a planned reduction in unemployment benefit contributions to the individual accounts by the employer. Such a system would expand access to childcare to more children and encourage greater female participation for those mothers for who childcare is a barrier to work, which is welcome. New survey data suggests that many inactive women would work if they had someone with whom to leave their children and new empirical evidence shows that having childcare establishments close to home increases the probability that the mother participates in the labour market.

27. Still, it may not be enough to increase the number of childcare places. Take-up of such programmes also needs to rise. More than $90 \%$ of families that do not send their children to formal childcare say they find it unnecessary because they can be taken care at home (CASEN, 2011). This may be related to a preference for maternal care or lack of trust on formal childcare, but it may also be due to information barriers. About $24 \%$ of mothers qualifying for free access to childcare for their children through the well regarded programme Chile Crece Contigo had never heard of it, according to the 2012 ELPI survey. The government should keep publicising childcare options, thereby effectively expanding parental choice. It will also be important to ensure that quality does not deteriorate as the system expands fast to accommodate new demand. A recent bill plans to improve standards for early childhood education centers.

28. The government could also strengthen trust in formal childcare to promote greater take-up. International evidence shows that other factors - such as parental education, participation in formal childcare and the quality of interaction between parents and children - have greater influence on a child's early development than maternal employment per se (Brooks-Gunn et al., 2010; Huerta et al., 2011). Furthermore, existing evidence suggests that there are benefits of attending formal childcare for disadvantaged children also for younger children, but of course the quality of childcare services is crucial in this respect (e.g. Melhuish 2004).

\section{Parental leave}

29. The government extended in 2012 state-funded maternity leave after birth from 12 to 24 weeks, several weeks beyond the OECD average, which is welcome. Existing studies suggest that relatively short periods of leave (below one year) can increase job continuity (Baker and Milligan, 2008) and mitigate the negative effect of leave on women's wages by shortening the return time to work (Berger and Waldfogel, 2004; Thévenon and Solaz, 2012).

30. As of 2012, mothers can also share leave with fathers, for 6 weeks or 12 weeks if the parents take the leave on a part-time basis. Even though only $0.6 \%$ of eligible fathers have asked for leave, the initiative is a welcome first step. The government should promote greater take-up among fathers, though. Fathers' greater involvement in childcare has beneficial effects on their children's cognitive and behavioural development (Baxter and Smart, 2011; Huerta et al., 2011 and 2013). It can also help to reduce the time mothers dedicate to childcare and contribute to breaking what seems to be a vicious cycle: the more leave and/or reduced working hours women take to take care of their children compared with men, the more difficult it is for them to advance in their careers. OECD experience suggests that greater take up of paternity leave can be encouraged by implementing "take-it or lose it" non-transferable leave following births for fathers in addition to maternity leave (OECD, 2012b). Evidence from Norway suggests that such 
a policy can substantially increase take-up among fathers. Some fathers even choose to take extended leave to raise their children, which can be a first step to greater shared family responsibilities.

\section{Flexible work arrangements}

31. Opportunities to work part time and in flexible workplace arrangements are also part of a well-designed package of family-friendly policies. Part-time work is possible and common in Chile, and most part-time jobs are taken up by women. However, it is important to facilitate a smooth transition between part-time work and full time work for those that want to work more hours to minimise the possible negative consequences of part-time work. In some cases part-time jobs can marginalise women in the labour market, especially if they are characterised by poor wages, short tenure and low training (OECD, 2009). These factors can reduce women's prospects of promotion or put them at higher risk of dropping out the labour force.

32. OECD experience shows that the combination of more flexible working hours with the provision of affordable childcare and longer hours of care and out-of-school care services can facilitate the increase in working hours among mothers (OECD, 2011a). In this respect, families would benefit from a more flexible approach to working hours, which are very strict in Chile. A bill is before Congress since 2010 to promote teleworking. It should be adopted. While this may not be a solution for all families, it may help some to manage childcare and other family commitments alongside work and thereby facilitate the labour force participation of some women.

\section{Helping the young transition from study to work}

33. Youth labour-market participation is lower than in other OECD and Latin American countries, largely reflecting poor basic skills and difficulties in going smoothly from study to work. In particular, relatively low PISA scores in reading, math and science suggest that many students leave compulsory education with a poor command of basic skills that feeds into poor workplace learning capacity. At the same time the high share of NEETs (Figure 5, Panel B) suggests that many young people have problems going from study to work, in part because of poor linkages between education and skills needed at work, as well as undeveloped networks.

\section{General education}

34. Improving the quality of compulsory education and facilitating access to good education for the most vulnerable groups will be important to improve youth employability. Education increases the chances of being employed and earning higher wages in the labor market. Individuals with tertiary education are more likely to be employed than those with an upper secondary education who in turn have a greater chance of being employed than those without an upper secondary education (Figure 8). 
Figure 8. Percentage of 25-64 year-olds in employment, by educational attainment level (2011)

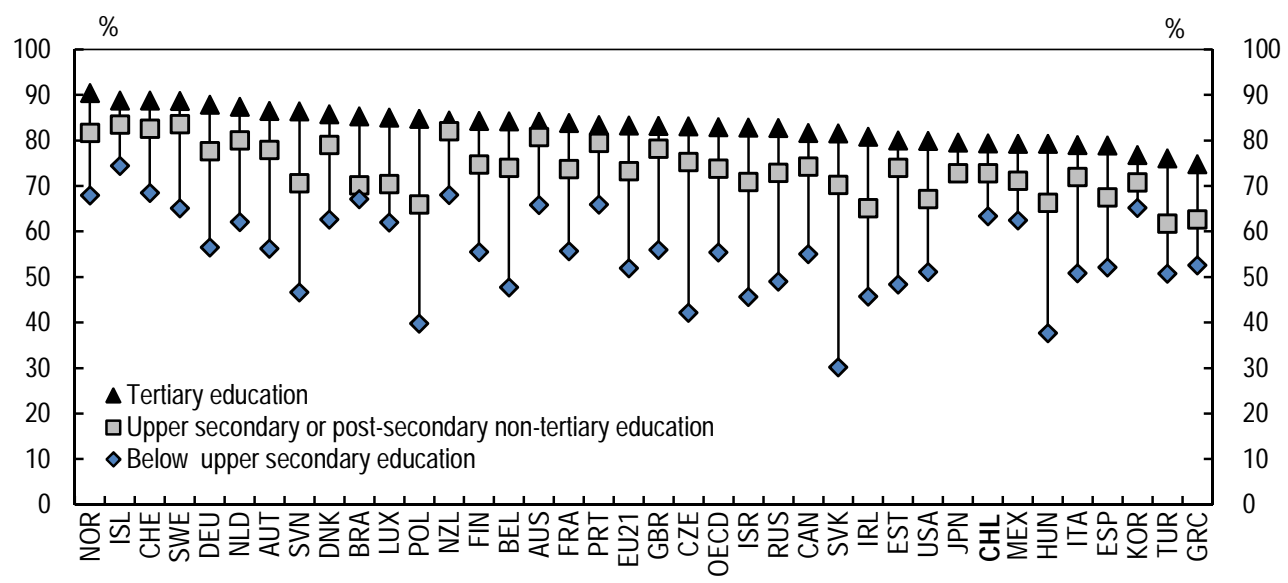

Source: OECD Education at a Glance (2013), Table A5.3b.

35. Chile has made impressive progress in educational attainment. The proportion of the population that has attained at least upper secondary education grew from 56\% for the generation aged 55-64 in 2011 to $88 \%$ for the generation aged $25-34$ in the same year. Lower secondary education is now virtually universal and enrolment rates for 15 to 19 year olds grew from $64 \%$ in 1995 to $76 \%$ in 2011 (OECD, 2011b).

36. It has also managed to significantly improve the quality of its education. Student learning outcomes in Chile, as measured by PISA, while still considerably below the OECD average, have remarkably improved over the past decade. For instance, Chile has the largest improvement between 2000 and 2009 in reading $(\mathrm{OECD}, 2010 \mathrm{a})$. Yet, Chilean students' results in reading, mathematics and science were among the lowest in the OECD area (OECD, 2010a). Moreover, the impact of socio-economic background on learning outcomes is well above the OECD average, although this indicator has also improved significantly between 2000 and 2009 .

37. In reaction to the inequities in access to the early stages of education, which are at the origin of ability gaps at later stages (OECD, 2010a), the government has increased the coverage of preschool education, made attendance to kindergarten free and compulsory, and provided additional funding for the schooling of socio-economically disadvantaged students. In addition, reforms seek to attract better prepared individuals to the teaching profession by granting scholarships to top students and giving bonuses to teachers and principals with excellent evaluations (OECD, 2013d). A draft law is in Congress proposing major changes in the organisation of the teaching profession including the introduction of a certification process to access the different levels of the teaching career (Santiago et al. 2013). The hiring of principals in public schools has also been professionalised and principals now have more liberty to select their management team and to dismiss teachers with bad evaluations. A new Quality of Education Agency (Agencia de Calidad de la Educación) was set-up in 2013 to evaluate the quality of learning provided by Chilean schools, including the evaluation of teachers, school principals and school providers. A complementary institution, the Education Superintendence (Superintendencia de Educación), will audit the use of public resources by school providers, supervise the compliance of school providers with standards, investigate complaints against schools and apply pertinent penalties. As recommended in the 2010 Economic Survey, better initial training of teachers, including tighter controls on the institutions providing the training, and better selection and evaluation of teachers, should also be a priority (Brandt, 2010; OECD, 2010b; Santiago et al. 2013). Indeed, evidence suggests that teacher quality has one of the most significant effects on educational achievement (OECD, 2011c). All of these reforms are expected to have a 
positive impact on the quality and equity of the education system, though they could have a sizable impact on public spending, and should remain funding priorities, especially in the early stages of education.

38. As recommended in past OECD Surveys, the government has also taken a number of steps to improve access and quality of tertiary education. In 2011, the government created a new agency responsible for quality assurance and enforcement of laws in higher education (Superintendencia de Educación Superior) (Annex 1).The government has also broadened scholarships and credits for lowincome students attending tertiary education. The number of scholarships for the most vulnerable $60 \%$ of the population has doubled, benefitting 220000 students in 2012. Interests on the guaranteed student loan (Crédito con Aval del Estado), which benefits mostly poorer students, including vocational training ones, were reduced from an annual $6 \%$ to $2 \%$ in 2012 . This lowers by $40 \%$ the monthly payments students need to make after they graduate from higher education, according to government figures. Congress has passed a bill that makes repayments to the guaranteed student loan (Crédito con Aval del Estado) incomecontingent. Introducing income-contingent loans was recommended in the 2012 Economic Survey, and is welcome as it will improve access to tertiary education for low-income students. These measures will facilitate access to higher-education of vulnerable students, without the regressivity that would be implied by making higher education free for all.

\section{Vocational education}

39. Investing in vocational education and training (VET) can yield economic returns, and countries with strong VET systems, like Germany or Australia, have been relatively successful at tackling youth unemployment (OECD, 2012c). This may be due to the fact that vocational education gives students skills that are immediately needed in the labour market. In Chile, however, vocational education is underdeveloped. While many students enrol in upper vocational education (around $40 \%$ of all students), the share of spending on vocational education is low compared with most OECD countries (OECD, 2009).

40. Curricula are outdated and the government has recently announced plans to update them and adapt them to the needs of the industry, which is welcome. The mechanisms to assure quality are often weak (MINEDUC, 2010). Poor quality assurance is particularly a problem in post-secondary education, where there is no mechanism to ensure basic standards on training or ex-post quality assessments. For tertiary vocational education, the same quality assurance framework as in university education applies, yet many institutions are not accredited, which suggests more needs to be done to enforce standards. Improving quality is the more important given the relatively poor educational background of students attending VET, and the poor qualification of teachers and trainers relative to the general education track (MINEDUC, 2010). Strengthening quality standards, attracting well-qualified teachers and trainers to vocational education and updating curricula could help to improve quality. Involving employers more closely in curricula design and strengthening the links between individual schools and employers could also be a way to ensure vocational education responds adequately to labour market needs.

41. It will also be important to reduce barriers to access and to moving within the VET system, and between different levels of the educational system. Scholarships (e.g. Beca Nuevo Milenio) and credits (Crédito con Aval del Estado) are available for tertiary vocational education, but they are small and few compared to those available for university education (MINEDUC, 2010). They may therefore need to be expanded. Once they are inside the VET system it is hard for students to move from upper secondary to tertiary VET education, as curricula and institutions are poorly interlinked. Renewed government efforts to develop a standardised qualification framework, discussed below, are a welcome attempt to improve mobility within the VET system and to develop pathways to university education.

42. Stronger emphasis on on-the-job training would also improve the skills and labour market prospects of VET graduates. As noted in an OECD review of Chile's vocational education (Kis and Field, 
2009) workplace training, as part of VET programmes, is poorly developed and the mechanisms to assure its quality are weak. Furthermore, another assessment suggest that as many as $40 \%$ of upper secondary VET students do not do the mandatory traineeship to receive their degree (MINEDUC, 2010). In tertiary education, some institutions include practical workplace training in their programmes while others do not. The OECD review of vocational training recommended that one option to encourage more students to acquire job experience would be to integrate the workplace training element into the body of upper secondary vocational programmes, rather than treat it separately, as it is today. This recommendation is still valid.

43. Strengthening cooperation and establishing effective partnerships with the private sector, as is planned, could also help to improve workplace training in vocational education. Other OECD countries' experience provides useful guidance on how to best achieve this objective. Experience from Austria, Australia, Germany and the United Kingdom suggests employers can be best engaged if there are broader institutional frameworks for them to participate in the design and provision of VET policy (Field et al. 2009; Kis and Field, 2009). These can be at the national level (as the UK Commission for Employment and Skills) or at the sectoral one (as the Australian Industry Skills Councils). Plans are in place to create "sector specific skills councils" to oversee the quality of publicly funded training and to identify sector specific skill needs, as described below. The role of these councils could be expanded beyond public training to cover VET. These councils could not only help to ensure there is a tight link between vocational education and the skills needed in the labour market, but also help to develop a stronger focus on workplace training in vocational education through the expansion of apprenticeships or internships.

\section{Youth training and apprenticeships}

44. Active labour market programmes, such as apprenticeships and training programmes, can also improve youth labour market outcomes, in particular for disadvantaged youth (OECD, 2010c; OECD, 2008). Chile has an apprentice programme targeted at workers aged 15-24 (Formación en el Puesto de Trabajo, Aprendices), as part of its public training programmes. The programme lasts twelve months and combines on the work-training with classroom-based training, where the apprentice receives half the minimum wage and the employer receives a training voucher to encourage it to provide additional training. The programme is now being evaluated; if successful it should be expanded to cover more youth.

45. Chile also has other training programmes (e.g. Formación para el Trabajo) which are designed to give youth basic skills necessary for job readiness (numeracy, basic computer courses etc) and which may also include internships. Given the large number of such programmes, it may be worthwhile to evaluate their effectiveness and eliminate those that do not work well and generate savings to expand those that do work well. Finally, evidence from other Latin American countries suggests that classroom-based courses do not have much impact, but that internship components generally do (OECD, 2013e). This suggests that the work-based training components should be strengthened, as was recently done with the programme Formación para el Trabajo Sectorial that focuses on transversal and technical skills and includes scholarships

46. While these training programmes can help to improve the labour market outcomes of disadvantaged youth, OECD experience suggests that positive results are difficult to sustain (OECD, 2009). If more large-scale training schemes are found necessary to improve the skills of youth, the objectives are more likely to be achieved by improving the quality of the education system and its connections with the needs of industries, as discussed above. 


\section{Working while studying}

47. To the extent that working hours are not too long (no more than 15-20 hours a week) during the school year, combining study and work, including apprenticeships, can facilitate the school-to-work transition (Figure 9 and OECD, 2010c, Scarpetta and Sonett, 2010). Yet, according to household surveys, in Chile, the percentage of students aged 15-29 who combine study and work is extremely low (below 6\% in 2009). A draft bill is before Congress that gives students aged 18 to 25 years old more flexible rules for working by establishing a contract through which the working day can be interrupted several times every day. This is welcome.

Figure 9. Combining study and work can be an effective pathway to enter the labour market Age 15-29, 2008

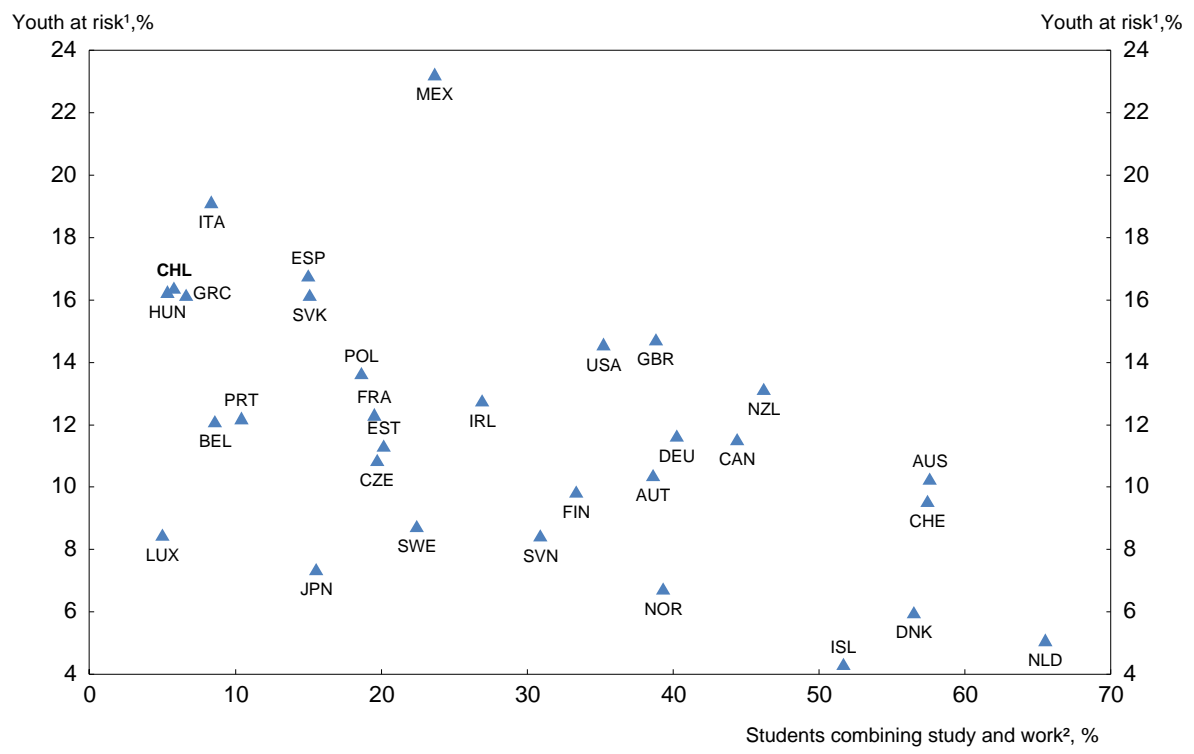

1. Youth who are not in education and are either unemployed or out of the labour force, in per cent of the population of the age group. For Chile, youth who are neither in education nor employed (2009).

2. Youth who are in education and are either employed or following in-work study programmes (including those on apprenticeships), in per cent of the age group in education. For Chile, youth who are studying and employed (2009).

Source: OECD, Education at a Glance 2010 and Off to a Good Start? Jobs for Youth; CASEN 2009.

\section{Reducing demand side barriers for hiring youth}

48. Youth also face demand-side barriers to employment. Since 2009, Chile has had an in-work benefit (Subsidio al Empleo Jóven) to increase youth employment. Employers receive one third of the benefit if they hire workers aged $18-25$ whose family belongs to the $40 \%$ poorest in the country, so as to encourage labour demand and as a means to reduce the minimum wage. The rest tops up employees' salaries (Consejo Trabajo y Equidad, 2008). The subsidy can reach up to $30 \%$ of wage income for those workers with the lowest wages and is withdrawn gradually with rising wages, complementing wage incomes and encouraging more people to work.

49. A recent evaluation of the benefit by the Centro de Microdatos (2012) shows the subsidy has been successful in increasing youth employment by about 3 percentage points. The take-up is however very low among employers (about 4\%), suggesting a relatively weak effectiveness in fostering labour demand. Possible reasons might include lack of information, incompatibilities with other subsidies or fear 
of labour inspections (Huneeus and Repetto, 2013). The government should investigate the sources of low employer participation and improve the design accordingly.

50. Chile has a high minimum wage of $67 \%$ of the median wage compared to an OECD average of $48 \%$ in 2011. While no evidence on the effect of the minimum wage on the employment of young workers exists for Chile, international evidence suggests that such a high minimum wage can dampen the demand for young workers or encourage informality (OECD, 2010c). This could be the case in Chile, where the minimum wage mainly affects the young and low-skilled workers (Castex, 2013). About 19\% of those aged 18 to 24 and $31 \%$ of low-skilled workers receive the minimum wage (210 000 pesos or 412 USD in 2013), compared to an average of $4 \%$ of all workers (CASEN, 2011).

51. Out of 25 OECD countries which have a statutory minimum wage, 13 have a lower one for youth, set at approximately around $70 \%$ of the adult minimum wage (OECD, 2013e). Chile does too, but only for workers under 18 years old, and consideration should be given to extending it to cover more young workers. Expanding coverage also involves risks, as reduced minimum wages for youth can institutionalise the incidence of low-pay jobs and lead to segmented labour markets with youth struggling to move to better paid jobs. Another option would be to expand apprenticeship contracts for low-skilled youth (Formación en el Puesto de Trabajo, Aprendices) to more young workers. These contracts are lowcost for employers and as they come with a voucher for training they can yield a double dividend if training is of good quality.

52. Strict employment protection also represents a barrier for hiring in Chile. There is a large asymmetry between the protection against dismissal for workers with indefinite contracts compared to those on temporary contracts, making firms reluctant to convert temporary contracts into permanent ones and leading to high turnover among temporary workers. Such high turnover can result in high costs for the individual in terms of lost income, high uncertainty, and lower possibilities for training. This may hinder productivity by reducing the incentives of firms and temporary workers to invest in training (e.g. Dolado et al., 2012). It has also been argued that such asymmetry will reduce the conversion rate of fixed-term contracts into permanent ones, thereby transforming fixed-term contracts into a trap rather than a stepping stone into more stable jobs (Boeri, 2011).

53. In parallel to the planned expansion of unemployment benefits described below, Chile should lower severance pay for permanent workers considerably, as recommended in the 2012 Economic Survey and in Going for Growth (OECD, 2013f). Youth are likely to be among the main beneficiaries. Evidence from Chile suggests that high protection of workers on permanent contracts is hurting the youth most, making their labour force participation and employment more difficult (Pagés and Montenegro, 2009).

\section{The low skilled need help to improve their skills and find better jobs}

54. Improved secondary and tertiary education attainment has already made many young Chileans better prepared for entering the labour market. But education and training policy must still reach out to numerous adults not eligible for higher education and who left education with poor skills, not least those working informally, where productivity tends to be lowest. While informality has a range of regulatory and structural causes, weak educational achievement is among the most important (Dougherty and Escobar, 2013). Good training and second-chance options for education can provide many of these workers a way out of low-skills poor-wage traps.

\section{In-work training}

55. Chile spends well above the OECD average on training, yet several assessments, including some commissioned by the government, have concluded that Chile's publicly funded training programmes are 
ineffective and poorly targeted at those who need it most (Larrañaga et al., 2011; OECD, 2012a, 2009). Around $75 \%$ of total public spending on training is allocated through tax credits to firms who send their workers on training with certified institutions (Franquicia Tributaria para la Capacitación). This programme benefits mostly large firms, which tend to already have highly educated workers (Castro and Viñaspre, 2011; Larrañaga et al., 2011). The programme has no measurable effect on salaries or employment in the long run, possibly because of the short duration of courses (Larranaga et al., 2011). One fifth of total spending is targeted to the most vulnerable, including women, youth and low-skilled workers through the National Training Fund (Fondo Nacional de Capacitación, FONCAP). While some of these programmes have significant positive impacts on employment and wages (Larrañaga et al., 2011), they are uneven.

56. The national training and employment service (SENCE) is undertaking reforms of the training system (Box 1) to establish an expert panel to guide training policies, as well as sector specific skill councils involving employers and unions to oversee the quality of publicly funded training and to identify sector specific skill needs. The reform will also strengthen the SENCE's technical capacity and allow it to investigate and sanction training providers not fulfilling minimum standards. A Qualification Framework is also under way to develop, classify and recognise skills and competencies along a continuum of levels, which ensures a clear training pathway.

57. In addition, the set-up of a national certification system for vocational skills, which has been under way since 2008, under the ChileValora programme, has recently regained momentum with renewed efforts to develop a quality assurance framework for training, including the setting up of vocational standards, occupational profiles and curricula for training courses based on industry standards.

\section{Box 1. Chile's plans to reform its public training system}

The national training and employment service (SENCE), which is in charge of training policies and administers training and job subsidy programmes, is working on a reform of the Training Act.

The reform aims at strengthening the role of the SENCE and ensuring better training policy design, implementation and evaluation. The main features of the reform are:

- $\quad$ Create an independent expert panel to evaluate the national training system. The members of the Expert Panel will be selected among well-renowned experts in the training and social policy fields.

- $\quad$ Set-up a new institutional framework to approve training packages, including the creation of Sector Skill Councils. These organisations will be in charge of identifying the occupational profiles that the industry will need in the short and medium-term, and proposing the relevant training packages. This will shift SENCE's expenditure from firm-specific training to more general skills, as demanded by companies and employees. The core functions of the Sector Skill Councils, which also include labour market intelligence reports in order to identify skill shortages throughout the industry, will be funded by the Ministry of Labour through performance-based agreements. Pilot projects have been set up in five sectors (mining, construction, forestry, agriculture and fisheries) to assess their feasibility.

- $\quad$ The new Training Act will improve the targeting of the tax-credit for training purposes (Franquicia Tributaria para la Capacitación) allowing only low-wage workers to benefit from it. Franquicia Tributaria will also become more flexible and market-oriented by introducing a price menu which will recognise different thresholds for this benefit according to real training costs, which differ among sectors and training methodologies.

- The reform will also improve the oversight of the processes and quality of the training national system. Fines and sanctions will substantially increase, and inspections will become more common. Simpler and faster cancellation procedures for those training providers charged with serious irregularities will be set-up. Moreover, regarding the quality of the system, a stricter accreditation system for training providers will be set-up based on performance in terms of salaries and employability of training programmes' students. 
This will be complemented by further measures to strengthen SENCE's technical capacity, by the means of technical assistance financed and supported by the Inter- American Development Bank. The technical assistance aims at:

- Increasing the quality of the training national system, particularly in the areas of program design, monitoring and evaluation.

- Reviewing SENCE's programs to ensure sound beneficiaries' targeting, early diagnoses and coordination between public services. It will also review and improve the relevance of training courses by the means of increasing private sector involvement.

- Enhancing SENCE's management capacity by re-designing management procedures, reviewing the role and scope of SENCE's regional units (Direcciones Regionales), and improving database management with the implementation of business intelligence software and a data warehouse.

58. These efforts go in the right direction. OECD experience suggests that all these elements are needed to develop successful skill strategies (OECD, 2012d). First, close collaboration between the private sector, government and unions in defining training policies can help to strike a balance between short-term firm-specific skills and broader and transferable skills needed across multiple sectors. Second, involving unions is a good way to ensure that workers' interests are protected and their skills are effectively used to improve job quality and salaries. Finally, widely recognised vocational skill certifications can improve employability and productivity by incentivising training and certifying skills gained informally through experience in the workplace, as for instance on-the-job training provided by small and medium enterprises (SMEs) that is often not formalised.

59. To ensure good training quality establishing regular performance assessments and disseminating information about providers can help. For training to be effective it will be important to set up mechanisms to ensure that providers supply courses that are relevant for the labour market. One way to achieve this could be to include students' employability as one of the performance measures for training institutions. Collecting such information could also help to build a database about how demand for skills changes over time that can help to guide training policies and complement the labour market intelligence reports planned by reform.

60. Training needs to be focused more on those who need it most (OECD, 2012a), including individuals who leave education with very weak skills. The government plans to confine tax breaks on training spending to low-wage workers, which is welcome, as it can provide an incentive for employers to send their low-skilled employees to training. Beyond this, OECD experience suggests that second-chance options for education can also help. For instance, some OECD countries have developed successful strategies to reach low-skill adults by combining different modes and purposes of learning, often in non-school environments (OECD, 2012d). A good example is Australia, which provides second-chance programmes that focus on combining school-based learning with on-the-job training, in a dual apprenticeship system for adults (OECD, 2012e). The programmes are short and intensive, and lead to a qualification similar to the conventional apprenticeship system for youth.

61. Skills strategies also need to be flexible enough to adapt to changing labour-market needs (OECD, 2012d). This can be achieved, for instance, through rapid-approval procedures for new training programmes and through systems that allow individuals to move easily between pathways, for example between vocational and academic tracks. An integrated government approach towards skills policies, covering training, vocational education and tertiary education can also help. This can be achieved by setting up a specialised agency coordinating national skill policies across several government areas to identify priorities, design strategies and support their implementation. It can also promote cost 
effectiveness by helping to determine how limited resources should be shared across different education and training needs.

\section{Unemployment insurance}

62. Strengthening unemployment insurance can better protect workers and improve economic efficiency (OECD 2012a, OECD 2013a). Unemployment insurance coverage has increased, but remains low for some groups. For instance, only half of all young workers are covered (ENCLA, 2011). Yet young people often need more help than others to find jobs, given their limited work experience and networks.

63. In the Chilean context, the 2012 Economic Survey recommended that reduced dismissal protection be accompanied by a more extensive unemployment benefit system, which is based on individual accounts with complements from an insurance fund (Fondo Solidario). Despite past reforms that extended access to benefits and prolonged benefit duration, funds accumulated in the individual savings accounts and the solidarity fund have kept growing providing an opportunity to increase benefits. The authorities have sent a bill to balance the fund by reducing contributions to the individual accounts by the employer by $1 \%$ and raising benefit initial replacement rates. As a result the replacement rates would increase from $57 \%$ to $70 \%$ (Figure 10 ).

Figure 10. The effect of the proposed unemployment benefit reform on replacement rates (net of taxes), $2011^{1}$

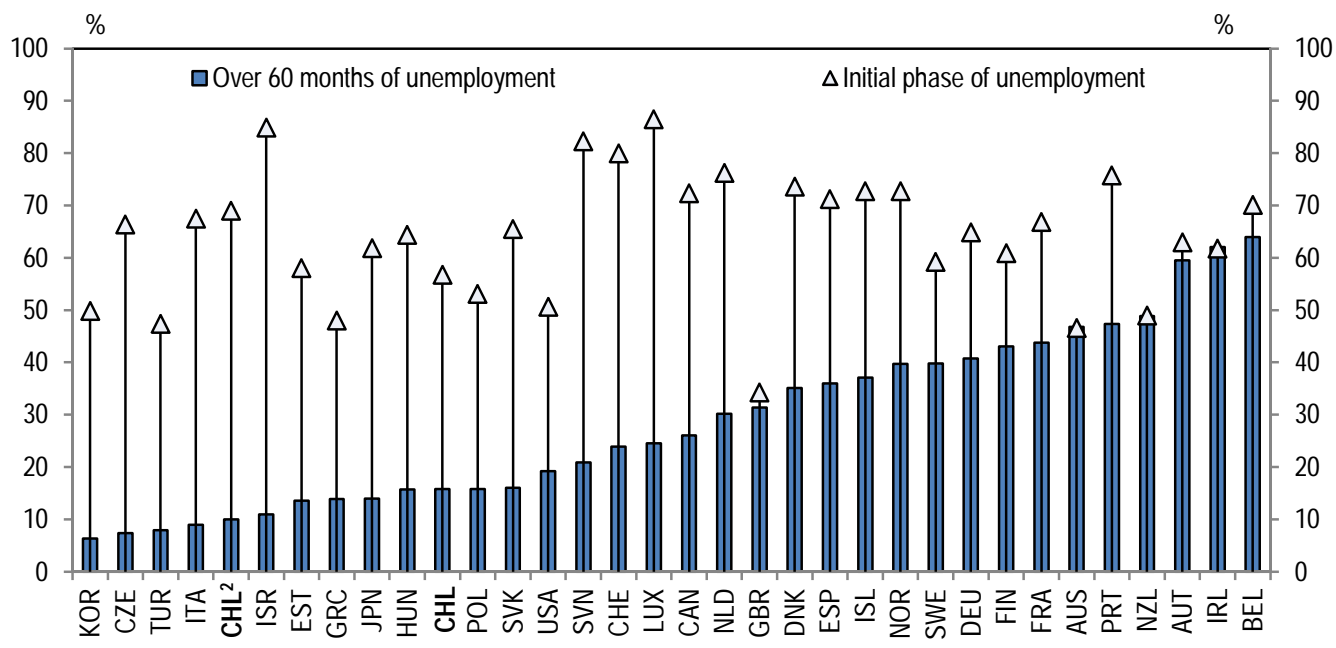

1. Unweighted averages (single and one-earner married couple with no children and lone parent and one earner married couple with two children) for earnings levels of $67 \%$ and $100 \%$ of average worker income, without social assistance.

2. Based on the proposed reform to the unemployment benefit system announced on 1 May 2013.

Source: OECD, Tax Benefits Models.

\section{Job search assistance}

64. To capitalise on the higher unemployment benefits, job-search monitoring and assistance, which is currently weak, should be made more effective. One advantage of the Chilean unemployment savings account system is that it tends to promote active job search among its recipients, as the unemployed first draw from their own savings before accessing the publicly funded benefits. Nevertheless public employment services can play an important role in matching labour demand and supply through the provision of information, placement and active support services for the unemployed and getting inactive workers into employment. 
65. In practice, however, only a small fraction of Chilean workers find employment through the public employment system and many find jobs through personal contacts and social networks (SchmidtHebbel et al., 2013). Most of Chile's local employment offices (Oficinas Municipales de Intermediación Laboral, OMILs) lack the administrative capacity to monitor search efforts, deliver appropriate job-search services, like basic job counselling and placement for the unemployed, let alone to help inactive workers. Those local offices that do perform well are located in relatively rich communes with high tax revenues, fewer hard to place clients or low unemployment.

66. Since 2006 a nationwide electronic platform (Bolsa Nacional de Empleo) brings together jobseekers and job vacancies, which can help some people find a job. According to official records, the annual flows of registered jobseekers and new vacancies are substantial compared with the size of the labour force. In 2012 there were 570000 registered jobseekers ( $8 \%$ of the labour force) and 728000 posted new vacancies. But the platform is not adequate for harder-to-place jobseekers, such as the long-term unemployed or first-time job seekers, who often need personalised employment counselling. Also as it is funded by the unemployment insurance system, only unemployed workers that are affiliated with the unemployed benefit system (about $60 \%$ of all workers) can use the electronic platform. The rest need to visit a local employment office.

67. Disadvantaged workers, such as women and older workers are likely to benefit the most from strengthened job assistance. They have a harder time finding jobs when unemployed and longer unemployment spells, with significant wage losses once they are reemployed and worse employment outcomes (OECD, 2013a; Granados, 2014).

68. Since 2009, additional funding has been directed to local offices (Programa de Fortalecimiento $O M I L)$ to hire staff or buy equipment. Successful job placement and retention of vulnerable beneficiaries is rewarded with additional funding. OECD experience suggests that the effectiveness of public, as well as private employment services can be improved through effective performance management (OECD, 2013c).

69. More recently, attempts have been made to engage private providers in job intermediation services. In 2012, a pilot programme was implemented to develop a network of private providers' through a publicly- funded voucher (Bono de Intermediación Laboral), which paid private sector job intermediation agencies for placing vulnerable jobseekers. But the programme failed, most of the providers lacked the technical expertise to successfully assist vulnerable clients.

70. A new pilot programme is to be launched in 2014. Following the UK system, two specialised intermediation offices will be tendered to private providers, which will act as monopolistic providers for 12 months within a geographical area, in partnership with several local employment offices. Private providers will deal with the "most hard to place clients", while local employment offices will focus on clients needing less help to find jobs. Local offices will act as gatekeepers and send clients that they assess as being too complex to successfully intermediate by themselves to private providers, whose payment will be based on performance based indicators of job placement and retention. At the same time, to strengthen the capacities of the local employment offices funding will be targeted to the most successful and promising local offices.

71. The pilot programme will also seek to improve coordination and strengthen the performance of the public employment services. Private providers will also be in charge of coordinating local employment offices and other related social services and provide them with technical assistance to improve their performance. In the medium term, once the planned reforms strengthen the national employment agency's capacity and the local employment offices, Chile could consider integrating the local employment offices into a nationwide network under the national employment agency responsibility. This way the agency could implement a policy of monitoring and enforcing the conditions for individual entitlement to 
nationally-financed unemployment benefits, which is difficult to ensure when local offices are autonomous or managed by local governments.

72. For private provision to work, there must be an active government-led management framework in charge of defining the target population, so that the system of fees for private agencies rewards their performance in terms of achieving sustainable job placements primarily for this target population, not a target population selected by the agencies themselves. For instance, in Australia, which has relatively low unemployment and high employment, and where employment services are delivered by contracted employment service providers, the department of employment successfully plays that role (OECD, 2013a). It defines complex contracts with employment service providers, including target population, maintains a national database of jobseeker characteristics, monitors and estimates comparative measures of employment service provider performance as the basis for renewing or terminating contracts. As the Australian and previous Chilean experiences show, involving private providers is not simple, hence the importance of testing the usefulness of private sector providers through pilot studies. This approach may not be cheap. Australia spends a bit above the average OECD country in job intermediation $(0.17 \%$ of GDP), and over ten times more than Chile, but its system tends to reward the right outcomes and ensure that only high-performing providers remain in the market leading to low unemployment.

\section{Box 2. Recommendations to improve labour market inclusiveness}

\section{Key recommendations}

- Increase female workforce participation by expanding high-quality childcare, promoting flexible working hours and providing non-transferable parental leave entitlements to fathers. To increase childcare take-up, continue to publicise the availability of childcare options.

- Boost youth employment by expanding the reduced minimum wage for youth under 18 to those under 25 years old and implementing the reformed apprenticeship contracts. In parallel with extending unemployment benefits, lower the relatively high severance pay for regular workers.

- Strengthen the public training framework through quality standards and performance assessments for training providers, and by better targeting low-skilled workers. Improve job search assistance by strengthening local employment offices.

\section{Other recommendations}

- $\quad$ Carry out pilot studies using private-sector providers for personalised job counselling of harder-to-place jobseekers.

- $\quad$ Strengthen vocational education by updating curricula, further developing work placement and by deepening the on-going standardised qualification framework to boost mobility.

- Extend unemployment benefits further, as planned, and exploit this by monitoring job search efforts and improving job search assistance.

- $\quad$ Eliminate the requirement for firms to finance childcare once they employ 20 women or more. 


\section{BIBLIOGRAPHY}

Baker, M. and K. Milligan (2008), "How does Job Protected Maternity Leave affect Mothers' Employment?”, Journal of Labor Economics, Vol. 26, No. 4, pp. 655-692.

Baxter, J. and D. Smart (2011), "Fathering in Australia among Couple Families with Young Children", Occasional Paper, No. 37, Department of Families, Housing, Community Services, and Indigenous Affairs, Australian Government.

Berger, L.M. and J. Waldfogel (2004), "Maternity Leave and the Employment of New Mothers in the United States", Journal of Population Economics, Vol. 17, No. 3, pp. 331-349.

Boeri, T. (2011), "Institutional reforms and dualism in European labor markets", in O. Ashenfelter and D.

Brandt, N. (2010), "Chile: Climbing on Giants' Shoulders: Better Schools for all Chilean Children”, OECD Economics Department Working Papers, No. 784.

Brooks-Gunn, J., W. Han and J. Waldfogel (2010), "First-year Maternal Employment and Child Development in the First 7 Years", Monographs of the Society for Research in Child Development, Vol. 75, No. 2, pp. 144-145.

CASEN (2009, 2011), Encuesta de Caracterización Socioeconómica Nacional, Ministerio de Desarrollo Social, Gobierno de Chile.

Castex, G. (2013), “Aumento del Salario Mínimo y sus Efectos sobre el Mercado Laboral”, Documentos de Trabajo, No. 690, Banco Central de Chile.

Castro, C. and R. Ruiz de Viñaspre (2011), "Foco y Uso de la Franquicia Tributaria", presentation, Ministry of Labour.

Centro de Microdatos (2012), "Evaluación de Impacto del Programa de Subsidio al Empleo Jóven", Informe Final, Centro de Microdatos, Departamento de Economía, Universidad de Chile.

Contreras, D., L. de Mello and E. Puentes (2008), "Encouraging Labour Force Participation in Chile", OECD Economics Department Working Papers, No. 608.

Contreras, D. and G. Plaza (2010), "Cultural Factors in Women's Labor Force Participation in Chile”, Feminist Economics, 16(2), 27-46.

Consejo Trabajo y Equidad (2008), Informe Final.

Dolado, J., S. Ortigueira and R. Stucchi (2012), "Does dual employment protection affect TFP? Evidence from Spanish manufacturing firms", CEPR Discussion Paper, No. 8763.

Dougherty, S. and O. Escobar (2013), “The Determinants of Informality in Mexico's States", OECD Economics Department Working Papers, No. 1043.

ENCLA (2011), Encuesta Laboral, Ministerio de Trabajo, Gobierno de Chile.

Field et al. (2009), Learning for Jobs: The OECD Review of Vocational Education and Training. Initial Report, OECD, Paris. 
Granados, P. (2014), "Displacement in Chile”, mimeo.

Heckman, James J. (2008). “Schools, skills, and synapses.” Economic Inquiry 46(3): 289-324.

Huerta, M. et al. (2013), "Fathers' Leave, Fathers' Involvement and Child Development: Are They Related? Evidence from Four OECD Countries", OECD Social, Employment and Migration Working Papers, No. 140, OECD Publishing. http://dx.doi.org/10.1787/5k4dlw9w6czq-en

Huerta, M.C.,W. Adema, J. Baxter, M. Corak, M. Deding,W.J. Han and J.Waldfogel (2011), "Early Maternal Employment and Child Development in Five OECD Countries", OECD Social, Employment and Migration Working Papers, No. 118.

Huneeus, C. and Repetto (2013), “Los desafíos pendientes del Ingreso Ético Familiar”, mimeo.

Immervoll, H. and M. Pearson (2009), "A good time for making work pay? Taking Stock of In-Work Benefits and Related Measures Across the OECD", OECD Social, Employment and Migration Working Papers, No. 81, OECD Publishing, Paris.

Kis, V. and S. Field (2009), "Learning for Jobs: OECD Reviews of Vocational Education and Training: Chile: A First Report", OECD, Paris.

Larrañaga et al. (2011), "Informe Final, Comisión Revisora del Sistema de Capacitación e Intermediación Laboral", Santiago de Chile, diciembre.

Lobo, W. (2014), "Determinants of Labour Supply of Mothers in Chile: The Role of Childcare", mimeo.

Medina F. and P. Paredes (2013), "Radiografía del Mercado Laboral Femenino en Chile", Horizontal Chile.

Melhuish, E.C. (2004). "Child benefits. The importance of investing in quality of child care".

MINEDUC (2010), "Educación Técnica Profesional en Chile: Antecedentes y Claves de Diagnóstico", Ministerio de Educación de Chile.

Miranda, V. (2011), "Cooking, Caring and Volunteering: Unpaid Work around the World", OECD Social, Employment and Migration Working Papers, No. 116.

OECD (2008), "Off to a Good Start? Youth Labour Market Transitions in OECD Countries", in OECD Employment Outlook 2008, OECD Publishing, Paris.

OECD (2009), “OECD Reviews of Labour Market and Social Policies: Chile”, OECD, Paris.

OECD (2010a), PISA 2009 Results: What Students Know and Can Do, Student Performance in Reading, Mathematics and Science, Vol. I, OECD, Paris.

OECD (2010b), Economic Survey of Chile, OECD , Paris.

OECD (2010c), Off to a Good Start? Jobs for Youth, OECD, Paris.

OECD (2011a), Doing Better for Families, OECD, Paris.

OECD (2011b), Education at a Glance, OECD, Paris. 
OECD (2011c), Building a High-Quality Teaching Profession: Lessons from Around the World, Paris.

OECD (2012a), Economic Survey of Chile, OECD, Paris.

OECD (2012b), Closing the Gender Gap, OECD, Paris.

OECD (2012c), OECD Education at a glance, OECD, Paris.

OECD (2012d), Better Skills, Better Jobs, Better Lives: A Strategic Approach to Skills Policies, Paris.

OECD (2012e), Activating Jobseekers: How Australia Does It, OECD, Paris.

OECD (2013a), Economic Survey of Chile, OECD, Paris.

OECD (2013b), OECD Employment Outlook 2013, OECD, Paris.

OECD (2013c), Recommendation of the Council on Gender Equality in Education, Employment and Entrepreneurship, Meeting of the OECD Council at the Ministerial Level, Paris, May.

OECD (2013d), Education Policy Outlook: Chile, OECD, Paris, forthcoming.

OECD (2013e), Investing in Youth: Brazil, OECD, Paris, forthcoming.

OECD (2013f), Going for Growth: Economic Policy Reforms, OECD, Paris.

Parro, F. and L. Reyes (2013), "The Chilean Labour Market: Job Creation, Quality, Inclusiveness, and Future Challenges", background document, OECD Survey.

Pagés, C. and C. Montenegro (2007), "Job Security and the Age Composition of Employment: Evidence from Chile", Estudios de Economía, Vol. 34. No. 2., pp. 109-139.

Politeia Soluciones Públicas (2007), "Modificaciones al permiso pre y postnatal y extensión de cobertura de salas cunas y jardines infantiles para hijos e hijas de mujeres trabajadoras", Informe Final.

Quintini, G., and T. Manfredi (2009), "Going Separate Ways? School-to-Work Transitions in the United States and Europe”, OECD Social, Employment and Migration Working Papers, No. 90.

Ruhm, C. and J. Waldfogel (2011), "Long-Term Effects of Early Childhood Care and Education”, IZA Discussion Paper, No. 6149, Bonn.

Santiago et al. (2013), OECD Reviews of Evaluation and Assessment in Education: Teacher Evaluation in Chile 2013, OECD, Paris.

Scarpetta, S. and A. Sonnett (2012), "Challenges Facing European Labour Markets: Is a Skill Upgrade the Appropriate Instrument?”, DOI: 10.1007/s10272-012-0402-2

Schmidt-Hebbel, K. et al. (2013), "95 propuestas para un Chile mejor”, El Grupo Res Pública Chile, www.95propuestas.cl

Thévenon, O. (2013) "Drivers of Female Labour Force Participation in the OECD," OECD Social, Employment and Migration Working Papers, No. 145.

Thévenon, O. and A. Solaz (2013) "Labour Market Effects of Parental Leave Policies in OECD. 
ECO/WKP(2014)13

\section{WORKING PAPERS}

The full series of Economics Department Working Papers can be consulted at www.oecd.org/eco/workingpapers

1116. Spillover effects from exiting highly expansionary monetary policies

(May 2014) by Łukasz Rawdanowicz, Romain Bouis, Jérôme Brezillon, Ane Kathrine Christensen and Kei-Ichiro Inaba

1115. Economic policies and microeconomic stability: a literature review and some empirics (April 2014) by Paula Garda and Volker Ziemann

1114. How to improve Israel's health-care system (April 2014) by Philip Hemmings

1113. How to improve taxes and transfers in Israel (April 2014) by Philip Hemmings

1112. New evidence on the determinants of industrial specialisation (April 2014) by Asa Johansson and Eduardo Olaberria

1111. Economic growth from the household perspective: GDP and income distribution developments across OECD countries

(April 2014) by Orsetta Causa, Sonia Araujo, Agnès Cavaciuti, Nicolas Ruiz and Zuzana Smidova

1110. Would a growth slowdown in emerging markets spill over to high-income countries? A quantitative assessment

(April 2014) By Patrice Ollivaud, Elena Rusticelli and Cyrille Schwellnus

1109. Short-term indicator models for quarterly GDP growth in the BRIICS: A small-scale bridge model approach

(April 2014) by Thomas Chalaux and Cyrille Schwellnus

1108. The prudential regulation of financial institutions: why regulatory responses to the crisis might not prove sufficient

(March 2014) by William R. White

1107. OECD forecasts during and after the financial crisis: a post mortem

(March 2014) by Nigel Pain, Christine Lewis, Thai-Thanh Dang, Yosuke Jin and

Pete Richardson

1106. Fairly sharing the social impact of the crisis in Greece

(January 2014) by Vassiliki Koutsogeorgopoulou, Manos Matsaganis, Chrysa Leventi and Jan-David Schneider

1105. Dividing the pie in Brazil: income distribution, social policies and the new middle class (January 2014) by Jens M. Arnold and João Jalles

1104. New indicators of competition law and policy in 2013 for OECD and non-OECD countries (December 2013) by Enrico Alemani, Caroline Klein, Isabell Koske, Cristiana Vitale and Isabelle Wanner 
1103. The effect of government debt, external debt and their interaction on OECD interest rates (December 2013) by David Turner and Francesca Spinelli

1102. The state of the banking sector in Europe (December 2013) by Dirk Schoenmaker and Toon Peek

1101. Getting Irish youth on the job track

(December 2013) by Alberto González Pandiella

1100. New econometric estimates of long-term growth effects of different areas of public spending (December 2013) by Omar Barbiero and Boris Cournède

1099. Cross-country spillovers from fiscal consolidations

(December 2013) by Antoine Goujard

1098. Informal employment in Russia: definitions, incidence, determinants and labour market segmentation

(December 2013) by Hartmut Lehmann and Anzelika Zaiceva

1097. Capacity needs in the automobile industry in the short- to medium run

(November 2013) by Caroline Klein and Isabell Koske

1096. Environmental policies and productivity growth - a critical review of empirical findings

(November 2013) by Tomasz Koźluk and Vera Zipperer

1095. Green growth challenges and the need for an energy reform in Mexico

(November 2013) by Carla Valdivia de Richter

1094. From bricks to brains: increasing the contribution of knowledge-based capital to growth in Ireland

(November 2013) by David Haugh

1093. China's march to prosperity: reforms to avoid the middle-income trap

(November 2013) by Vincent Koen, Richard Herd and Sam Hill

1092. Multi factor productivity with natural capital

(November 2013) by Nicola Brandt, Paul Schreyer and Vera Zipperer

1091. Growth-promoting policies and macroeconomic stability

(November 2013) by Douglas Sutherland and Peter Hoeller

1090. Policies for inclusive urbanisation in China

(October 2013) by Vincent Koen, Richard Herd, Xiao Wang and Thomas Chalaux

1089. Fiscal devaluation - can it help to boost competitiveness?

(October 2013) by Isabell Koske

1088. How to achieve growth- and equity-friendly fiscal consolidation? A proposed methodology for instrument choice with an illustrative application to OECD countries

(October 2013) by Boris Cournède, Antoine Goujard and Álvaro Pina. 